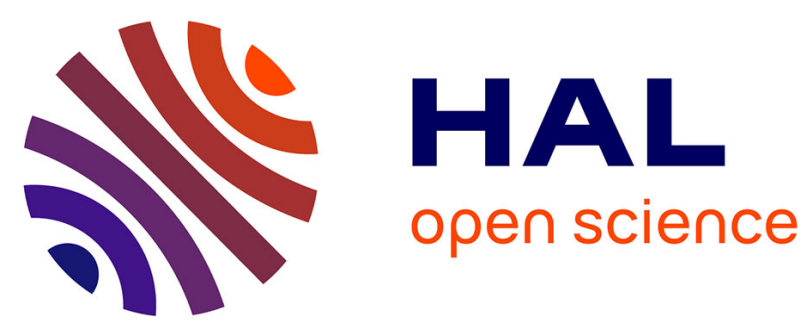

\title{
Starting to unravel the toxoglossan knot: Molecular phylogeny of the "turrids" (Neogastropoda: Conoidea)
}

N. Puillandre, S. Samadi, M.-C. Boisselier, A.V. V Sysoev, Y.I. I Kantor, C. Cruaud, A. Couloux, P. Bouchet

\section{- To cite this version:}

N. Puillandre, S. Samadi, M.-C. Boisselier, A.V. V Sysoev, Y.I. I Kantor, et al.. Starting to unravel the toxoglossan knot: Molecular phylogeny of the "turrids" (Neogastropoda: Conoidea). Molecular Phylogenetics and Evolution, 2008, 47 (3), pp.1122-1134. hal-02002424

\section{HAL Id: hal-02002424 \\ https://hal.science/hal-02002424}

Submitted on 31 Jan 2019

HAL is a multi-disciplinary open access archive for the deposit and dissemination of scientific research documents, whether they are published or not. The documents may come from teaching and research institutions in France or abroad, or from public or private research centers.
L'archive ouverte pluridisciplinaire HAL, est destinée au dépôt et à la diffusion de documents scientifiques de niveau recherche, publiés ou non, émanant des établissements d'enseignement et de recherche français ou étrangers, des laboratoires publics ou privés. 
Starting to unravel the toxoglossan knot: Molecular phylogeny of the "turrids" (Neogastropoda: Conoidea)

3

4

N. Puillandre ${ }^{\text {a,b, }}$, S. Samadi ${ }^{\text {a }}$, M.-C. Boisselier ${ }^{\text {a }}$, A.V. Sysoev ${ }^{\text {c }}$, Y.I. Kantor ${ }^{\text {d }}$,C. Cruaud ${ }^{\text {e }}$, A. Couloux ${ }^{\mathrm{e}}$, P. Bouchet ${ }^{\mathrm{b}}$

${ }^{a} U M R$ 7138, Syste'matique, adaptation, e'volution, UPMC, IRD, MNHN, CNRS, Service de syste'matique mole'culaire (CNRS, IFR 101), Département systématique et évolution, Muséum National d'Histoire Naturelle, CP26, 57 rue Cuvier, 75231 Paris Cedex 05, France

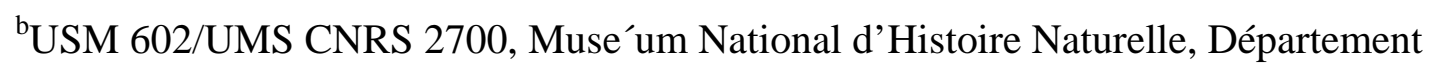
Syste'matique et E’ volution, 55 rue Buffon, 75231 Paris Cedex 05, France

${ }^{\mathrm{c}}$ Zoological Museum of Moscow State University, Bolshaya Nikitskaya str. 6, Moscow 103009, Russia

${ }^{\mathrm{d}}$ A. N. Severtzov Institute of Ecology and Evolution, Russian Academy of Sciences, Leninski prospect 33, Moscow 119071, Russia

${ }^{\text {e}}$ GENOSCOPE, Centre National de Séquençage, 2 rue Gaston Crémieux, CP 5706, 91057 Evry Cedex, France

*Corresponding author. Address: UMR 7138, Systématique, adaptation, évolution, UPMC, IRD, MNHN, CNRS, Service de systématique moléculaire (CNRS, IFR 101), Département Systématique et Evolution, Muséum National d’Histoire Naturelle, CP26, 57 rue Cuvier, 75231 Paris, Cedex 05, France.

E-mail address: puillandre@mnhn.fr (N. Puillandre). 


\begin{abstract}
The superfamily Conoidea is one of the most speciose groups of marine mollusks, with estimates of about 340 recent valid genera and subgenera, and 4000 named living species. Previous classifications were based on shell and anatomical characters, and clades and phylogenetic relationships are far from well assessed. Based on a dataset of ca. 100 terminal taxa belonging to 57 genera, information provided by fragments of one mitochondrial (COI) and three nuclear (28S, 18S and H3) genes is used to infer the first molecular phylogeny of this group. Analyses are performed on each gene independently as well as for a data matrix where all genes are concatenated, using Maximum Likelihood, Maximum Parsimony and Bayesian approaches. Several well-supported clades are defined and are only partly identifiable to currently recognized families and subfamilies. The nested sampling used in our study allows a discussion of the classification at various taxonomical levels, and several genera, subfamilies and families are found polyphyletic.
\end{abstract}

Keywords: 18S rRNA; 28S rRNA; Classification; COI gene; Conoidea; Conidae; H3 gene; Molecular phylogeny; Toxoglossa; Turridae; West Pacific 


\section{Introduction}

The superfamily Conoidea (= Toxoglossa) includes small to medium (3-50 mm on average) sized species of marine snails that are specialist predators on annelids, other mollusks, and even fishes, and occupy all marine habitats from the tropics to the poles, from shallow to deep water, and from hard to soft substrates. This is the most diverse groups of marine mollusks, with almost 700 recent and fossil nominal genera and 10,000 described species (Bouchet, 1990), and current estimates of about 340 recent valid genera and subgenera (Taylor et al., 1993) and 4000 named living species (Tucker, 2004). Conus alone includes over 500 valid species, making it the most speciose genus of marine animals (Kohn, 1990; Duda and Kohn, 2005). The monophyly of the Conoidea, characterized by a venom apparatus, is not questioned (Taylor et al., 1993), but subdivisions within Conoidea, and relationships between them are controversial, mostly because the extensive morphological and anatomical variation encountered is itself not well understood. In this context, molecular data can bring new characters, allowing to root the classification of Conoidea in an evolutionary perspective using a phylogenetic analysis.

During most of the 19th and 20th century, classifications (e.g., Fischer, 1887; Cossmann, 1896; Hedley, 1922; Thiele, 1929; Wenz, 1938-1944) were based on characters of the shell and of the radula, and Powell $(1942,1966)$ later gave emphasis on characters of the protoconch (larval shell). All these authors traditionally recognized three families of recent Conoidea: (i) Conidae, only containing the genus Conus, (ii) Terebridae containing species with acuminate shells without a siphonal canal, and (iii) Turridae, including the rest, i.e., the vast majority of the group. Turridae was considered by Hedley (1922) to be "more perplexing than any other molluscan family". Powell's $(1942,1966)$ subdivision of the Turridae in nine subfamilies (see Table 1) was the basis for turrid classifications in the latter half of the 20th century. Subsequent authors diverged on the number of subfamilies they recognized, mostly splitting one subfamily into several: working mainly on East Pacific faunas, McLean (1971) thus recognized 15 subfamilies of Turridae; Kilburn (various papers from 1983 to 1995) recognized eight subfamilies in the South African fauna; while in their monograph of European deep-sea turrids, Bouchet and Ware'n (1980) criticized the use of "'more or less randomly selected shell characters" and did not use subfamilies at all. Other shell- and radulabased classifications, mostly regional, include Morrison (1965), Shimek and Kohn (1981) and Chang (1995, 2001). A turning point in toxoglossate classification was the work of Taylor et al. (1993) who extensively used anatomical characters, in addition to radulae. Their entirely novel classification recognized six families (Conidae, Turridae, Terebridae, Drilliidae, Pseudomelatomidae and Strictispiridae), the salient point being that Conidae was by then enlarged beyond Coninae (Conus) to include five subfamilies previously placed in Turridae, and the newly restricted Turridae included a further five subfamilies. Bouchet and Rocroi's (2005) recent review of gastropod classification essentially kept Taylor's classification with updates based mainly on Rosenberg (1998) and Medinskaya and Sysoev (2003): Clavatulinae was raised to the family level; Taraninae was synonymized with Raphitominae; and the novel subfamily Zemaciinae was accepted in the Turridae. Thereafter, we use "Turridae s.l." to designate all Conoidea except Conus and Terebridae (i.e., Turridae sensu Powell (1966) and most 20th century authors) and "Turridae s.s." to designate the family as restricted by Taylor et al. (1993), while "Conidae" designates the expanded family after Taylor et al. (1993). Since Taylor et al. (1993), several anatomical studies have highlighted the high level of homoplasy of the characters of the shell and the radula (e.g., Kantor and Taylor, 1994; Kantor et al., 1997; Taylor, 1994), but although Conus itself has been subjected to intensive molecular studies (e.g., Duda and Kohn, 2005), the phylogeny of the broader Conoidea has not yet been addressed based on molecular characters. The present paper is thus the first 
molecular phylogeny, based on fragments of one mitochondrial and three nuclear genes, of the crown clade of the Caenogastropoda. It provides insights at several taxonomic levels (generic, subfamilial and familial) and the adequacy of previous classifications is thus reevaluated.

\section{Materials and methods}

\subsection{Taxon sampling}

Because of the instability of the taxonomy of the group, currently accepted synonymies cannot be taken for certain and must be re-evaluated. Ideally, a molecular sampling should thus include several representatives of all the nominal family group-names, including their type genera, whether they are currently regarded as taxonomically valid or not. In practice, this goal is difficult or impossible to reach because (a) a number of nominal (sub)families are based on fossil type genera (e.g., Borsoniinae, Conorbinae), and (b) a number of type genera are restricted in distribution and/or live in deep water and are difficult to obtain alive (e.g., Pseudomelatomidae, Thatcheriidae). To overcome these difficulties, our taxon sampling includes several genera for as many as possible of the subfamilies proposed in the literature (see detail in Table 1). Of the 114 specimens sequenced, few were replicates and the taxon sampling represents about 100 species in 57 valid genera.

\subsection{Materials}

The bulk of the material was obtained during expeditions carried out in the tropical western Pacific during research expeditions by the Muse'um National d'Histoire Naturelle (MNHN) and the Institut de Recherche pour le De'veloppement (IRD) (see Table 2). Living specimens were anesthetized using $\mathrm{MgCl}$, a piece of tissue was cut from the head-foot, and fixed in 95\% ethanol. This dataset was supplemented by specimens collected in West Africa by Serge Gofas in the mid 1980s. Shells were kept intact for identification. Identifications were carried to genus level using the classically admitted shell-based genus definitions, but, given the chaotic state of turrid systematics, no attempt was made to identify our material to species level; a number of species, especially from deep water, probably represent new species. Even so, eight specimens could not confidently be attributed to a genus and are denoted thereafter “cf. Genus". Conversely, specimens of Terebridae and Conus were identified to species level. A specimen of a species of Nassaria and a specimen of a species of Cancellopollia, both in the neogastropod family Buccinidae, closely related to Conoidea (Harasewych et al., 1997; Colgan et al., 2007), were used as outgroups. Littorina littorea, belonging in the nonneogastropod family Littorinidae, was used as a third outgroup, with sequences taken from GenBank (GenBank Accession Nos: AJ622946.1, Q279985.1, AJ488712.1 and DQ093507.1). Outgroups were chosen to form a non-monophyletic group, as recommended by Darlu and Tassy (1993). All vouchers are kept in MNHN.

\subsection{Sequencing}

DNA was extracted from a piece of foot, using 6100 Nucleic Acid Prepstation system (Applied Biosystem) or DNeasy

96 Tissue kit (Qiagen) for smaller specimens. A fragment of 658 bp of Cytochrome Oxidase I (COI) mitochondrial gene was amplified using the universal primers LCO1490 and HCO2198 
developed by Folmer et al. (1994). Three nuclear gene fragments were also analyzed: (i) 900 bp of the rDNA 28S gene, involving D1, D2 and D3 domains (Hassouna et al., 1984), using the primers C1 and D3 (Jovelin and Justine, 2001); (ii) 328 bp of the H3 gene using the primers H3aF and H3aR (Okusu et al., 2003); (iii) 1770 bp of the 18S gene using three pairs of primers: $1 \mathrm{~F}$ and 5R, 3F and Bi, A2 and 9R (Giribet et al., 1996; Okusu et al., 2003). All PCR reactions were performed in $25 \mathrm{ll}$, containing $3 \mathrm{ng}$ of DNA, 1reaction buffer, $2.5 \mathrm{mM}$ $\mathrm{MgCl} 2,0.26 \mathrm{mM}$ dNTP, $0.3 \mathrm{lM}$ of each primer, 5\% DMSO and 1.5 U of Q-Bio Taq (Qbiogene) for all genes. Amplifications consisted of an initial denaturation step at 94 C for 40 , followed by 30 cycles of denaturation at 94 C for 3000, annealing at 52 $\mathrm{C}$ for 28S gene and first and third fragment of $18 \mathrm{~S}$ gene, and 53 C for $\mathrm{H} 3$ gene and second fragment of $18 \mathrm{~S}$ gene for 4000 and extension at 72 $\mathrm{C}$ for 10 . The final extension was at 72 C for 100. COI gene amplifications followed description of Hebert et al. (2003). PCR products were purified using ExonucleaseI and Phosphatase and sequenced using BigDyeTerminator V3.1 kit (Applied biosystem) and the ABI3730XL sequencer. Because of the length of the 28S PCR product, two internal primers (D2 and C20, Dayrat et al., 2001) were used for sequencing, in addition of primers used for PCR. All genes were sequenced for both directions to confirm accuracy of each sequence. The overlap of the three fragments of $18 \mathrm{~S}$ gene made it possible to check for consistency. Sequences were deposited in GenBank (GenBank Accession Nos: EU015417-EU015858).

\subsection{Phylogenetic analyses}

COI and H3 genes were manually aligned whereas $28 \mathrm{~S}$ and $18 \mathrm{~S}$ genes were automatically aligned using ClustalW multiple alignment implemented in BioEdit version 7.0.5.3 (Hall, 1999). The accuracy of automatic alignments was confirmed by eye. Hyper-variable regions of $28 \mathrm{~S}$ gene and 30 extremity of $18 \mathrm{~S}$ gene were excluded from further analyses due to ambiguities in the alignments. For protein coding genes (COI and H3), saturation according to codon position was tested by plotting genetic distances against patristic distances calculated from a Maximum Parsimony (MP) tree with a heuristic search option, 10 random taxonaddition (RA) and tree-bisection and reconnection (TBR) branch-swapping using PAUP 4.0b10 (Swofford, 2002).

Nucleotide substitution models were selected for each gene separately and for each combined dataset using the program Modeltest (Posada and Crandall, 2001), in conjunction with PAUP 4.0b10 (Swofford, 2002). Best models and parameters as estimated by the AIC criterion were used for Maximum Likelihood (ML) analyses; only the model was fixed for Bayesian Analyses (BA). Analyses were conducted using three different approaches. A heuristic MP search was executed with 100 RA, TBR branchswapping, all sites equally weighted and indels treated as fifth states, using PAUP 4.0b10 (Swofford, 2002). ML heuristic search was conducted with 100 replicates with TBR branch-swapping using PhyML 2.4.4 (Guindon and Gascuel, 2003). Robustness of the nodes was assessed using nonparametric bootstrapping (Felsenstein, 1985) with 100 bootstraps replicates for MP analysis and 1000 for ML analysis, TBR branch-swapping and 100 RA replicates. BA consisted of six Markov chains $(8,000,000$ generations each with a sampling frequency of one tree each hundred generations) run in two parallel analyses using Mr. Bayes (Huelsenbeck et al., 2001). When the log-likelihood scores were found to stabilize, a consensus tree was calculated after omitting the first $25 \%$ trees as burn-in. For the treatment of combined data using BA, the data were separated into four unlinked partitions corresponding to the four genes analyzed, each following the best fitting model of substitution estimated for each gene. 


\subsection{Turning the phylogeny into a classification}

There are currently 41 available family-group names in the Conoidea, of which 19 are considered valid at family or subfamily ranks (Bouchet and Rocroi, 2005). In a nomenclatural perspective, only the occurrence of the type genus of a family-group name in a clade allows an unequivocal application of this name to that clade. For example, the clade containing the genus Raphitoma can unambiguously carry the name Raphitominae. However, many type genera are not represented in our taxon sampling and many of our molecular clades do not include a type genus. In such cases, we have relied on the traditional allocation of non-type genera to a subfamily to link clade and name. For example, a clade containing three genera classically classified in the family Drilliidae (Taylor et al., 1993; Tippet and Tucker, 1995) can carry the name Drilliidae, even though Drillia itself is not part of our taxon sampling. However, this approach does not lead to an unequivocal application of names when genera (or subfamilies) as traditionally construed prove to be non-monophyletic; in that case, only the type species (or the type genus) is the legitimate bearer of the name.

\section{Results}

For COI and H3 genes, 658 and 328 bp were sequenced, respectively, and no indels were found. After the alignment, we obtained a fragment of 933 and 1729 bp in length for the 28S and 18S genes, respectively. Sequencing of specimens belonging to genera Clavatula, Pusionella and Perrona was successful only for the COI gene: the prolonged conservation in the museum collections (more than 20 years) may have altered the quality of the DNA. Only one specimen (17855) failed to sequence for COI gene, and three others (17842, 17919 and 17920, genus Cochlespira) for H3 gene. No bias was detected in base composition. The saturation analyses for the two protein coding genes revealed that the COI gene was highly saturated on the third position of codon, thus we used only the first and second positions in the phylogenetic analyses. Best model and parameters estimated for each gene and genes combinations are shown in Table 3. Independent analyses of each of the four genes provided very poorly resolved trees, with few well-supported clades (Table 4).

The only incongruencies found between the independent gene analyses corresponded to poorly supported nodes. The most supported incongruency concerned relationships between three specimens attributed to the genus Bathytoma (17700, 17865 and 17857). In the ML analysis of H3 gene 17700 was the sister-group of 17865 and 17857 whereas in the ML analysis of the $18 \mathrm{~S}$ gene 17865 was the sister-group of 17700 and 17857 .These two nodeswere supported bybootstrap value of, respectively, 61 and 67, values weaker than the bootstrap value allowing the recognition of a supported clade (e.g., Hillis and Bull, 1993; Soltis and Soltis, 2003).

Since no incongruency was revealed among the single gene analyses, we constructed two combined datasets comprising the data of the 4 gene fragments resulting in a sequence of 3428 bp length. For both combined datasets we excluded the taxa attributed to Clavatula, Pusionella and Perrona for which only the COI gene was successfully obtained. For the first combined dataset (CD1) we also excluded the specimens 17855, 17842, 17919 and 17920, not sequenced for all genes, to avoid potential perturbation of phylogenetic reconstruction by missing data (Wiens, 1998). Thus, the CD1 included 104 ingroups and the second combined dataset (CD2) included 108 ingroups. In CD2, missing sequences were treated as missing characters in all analyses. For CD1 and CD2, respectively, 662 and 671 sites were variable among which 454 and 460 were parsimony informative. 
The Conoidea were found monophyletic, at least with the two combined analyses, although not always strongly supported (for CD2, MP and ML bootstraps, respectively: 65 and 79, Posterior Probabilities PP: 1).Within the Conoidea, two clades could be distinguished: clade A (MP bootstraps: 58, ML bootstraps: 68, PP: 0.73) and clade B (MP bootstraps: 28, ML bootstraps: 52 , PP: 1 ). Within the clade $A$, the clade $C$ is found strongly supported with ML bootstraps (91) and PP (1). Each analysis of the two combined datasets allowed the definition of the same 21 higher level clades, each of them strongly supported: MP andML bootstraps $>80$ and PP >0.99 (Mason-Gamer and Kellogg, 1996; Zander, 2004). They included from 1 to 12 genera each (Tables 4 and 5, Fig. 1). Clades were numbered according to their position in the tree (Fig. 1). Clades 1-9 are included in clade A, and among them clades 1-4 are included in clade C. Clades 10-21 are included in clade B.

As long branches, for example that displayed by clade 9, could potentially disturb phylogenetic reconstructions (Felsenstein, 2004), the three analyses (MP, ML and BA) were conducted for the whole CD2, excluding specimens 17701 and 17702 (clade 9). The Conoidea were again separated in two clades: A0 (including clades 1-8) and B. The boostraps and PP were increased for both clades A0 (MP Bootstraps: 60, ML bootstraps: 77, PP: 1) and clade B (MP Bootstraps: 37, ML bootstraps: 60, PP: 1).

The position of the representatives of Clavatula, Pusionella and Perrona, for which we obtained only the COI sequence, could be analyzed only in the single gene analysis. The taxa clustered in the weakly supported clade 22 in all the performed COI gene analyses (Table 4, tree not shown). The weak resolution of the trees obtained with the COI gene did not permit the placement of clade 22 in either clade A or B.

All representatives of a genus clustered together in 1 of the 22 clades, except representatives of Borsonia, Comitas, Conus and Leucosyrinx. The representatives of Borsonia and Conus splitted, respectively, in clades 15, 16 and 19-21, each including only specimens from a single genus. The relationships between the two clades were not resolved and thus the monophyly of each of these genera cannot be rejected. Conversely, the monophyly of genera Leucosyrinx and Comitas (clades 3, 4 and 9) can be rejected, since representatives of the two genera clustered in the clade 4.

\section{Discussion}

\subsection{Classification of the Conoidea}

Although not strongly supported, our analysis suggests that the superfamily Conoidea is monophyletic. However, the Conoidea and two outgroups used here (Cancellopollia and Nassaria) both belong in the Neogastropoda, the phylogeny of which is not well resolved (Harasewych et al., 1997; Colgan et al., 2007), and the monophyly observed here could thus be an artifact due to under-sampling within Neogastropoda. Within Conoidea, the large amount of diversity included in our dataset allows us to discuss the current classification at genus, subfamily, and family levels.

\subsection{Accuracy of taxonomic delimitations at genus level}

The genus is the lowest level for which we can discuss taxonomic delimitations since most of our specimens are not identified at species level. Among the 57 genera identified in our dataset, monophyly can be rejected for only two of them (Leucosyrinx and Comitas), which indicates that in most cases shell morphology is an appropriate predictor of generic allocations. Two further genera (Borsonia and Conus) are found to be diphyletic, but the position of the two defined clades is unresolved and thus monophyly cannot be excluded. 
Similarly, the polyphyly of some genera within the clades 1-22 can not be confirmed because of the lack of support for intra-clade nodes (results not shown).

\subsection{Position of the genera within the subfamilies}

Our analysis confirms many previous assignments of genera to subfamilies as in Taylor et al. (1993) (Table 1) and subsequent refinements of their classification. We thus confirm a position of Conopleura in the Drilliidae (Tippet and Tucker, 1995), of Anacithara in the Crassispirinae (Kilburn, 1994), of Turridrupa in the Turrinae (Kantor et al., 1997), of Toxicochlespira in the Mangeliinae (Sysoev and Kantor, 1990), and of Glyphostomoides in the Raphitominae (Shuto, 1983). However, several results do not confirm established classifications (Tables 1 and 5). The genus Otitoma, tentatively retained by Kilburn (2004) in the Mangeliinae based on shell characters, is here found to be in the Crassispirinae. The genus Lienardia, earlier classified in the Mangeliinae, is here placed in clade 12, identified as a Clathurellinae. (Furthermore, specimens attributed to Lienardia display several types of protoconchs and Lienardia as currently understood is probably a highly polyphyletic assemblage of species, some belonging to Raphitominae-not represented in our molecular sampling — and others to Clathurellinae — as the specimens studied here). The position of Gemmuloborsonia, assigned to the Turrinae (Sysoev and Bouchet, 1996; Medinskaya, 2002), is unresolved.

\subsection{Robustness of subfamilies delimitations}

We found discrepancies between our phylogeny and previous classifications at the subfamily level. Thus, crassispirine genera are present in two clades (2 and 7), one of them (clade 2) containing the type genus. The polyphyly of this subfamily is supported by the existence of clade $\mathrm{C}$, which includes clade 2 , but excludes clade 7 . Since the relationships between clade 7 and others clades within clade A are not resolved, it is unconclusive whether clade 7 must be ranked as its own subfamily or whether it must be grouped together with another existing subfamily. The subfamily Cochlespirinae as currently construed appears polyphyletic too, with four distinct clades (3, 4, 8 and 9), one of them (clade 8) containing the type genus. As for the Crassispirinae, the polyphyly of the Cochlespirinae is supported by the existence of clade $\mathrm{C}$, which includes clades 3 and 4, but excludes clades 8 and 9. However, because of the limits of the resolution of the deeper nodes, it is inconclusive whether clades 3 and 4 should be allocated to the Crassispirinae or should constitute a new subfamily; the subfamily Cochlespirinae could be limited to clade 8, or could also include clade 9 .

In the next three cases, polyphyly is possible but not demonstrated because of a general lack of support for deeper nodes in clade B. (a) Relationships between the two highly divergent clades (clades 11 and 17) of the Mangeliinae are not resolved and our results are inconclusive on the non-monophyly of the subfamily. (b) Coninae also ends up as two distinct clades (clades 19 and 21), a result already obtained by Duda and Kohn (2005). (c) The subfamily Clathurellinae is split into seven clades (clades 12, 13, 14, 15, 16, 18 and 20), but the nonmonophyly of these clades is not demonstrated. With one exception, our molecular clathurelline clades correspond to intra-clathurelline "groups" defined by Taylor et al. (1993), suggesting that these may warrant formal naming as tribes. The exception is clade 18 which includes on one hand the genus Typhlomangelia (placed in the "borsoniid group" by Taylor et al., 1993) and on the other hand the genera Heteroturris and Microdrillia (placed in the “ ‘tomopleurid group” by Taylor et al., 1993). 


\subsection{Robustness of families delimitations}

Finally, our results also permit a discussion of family classification within Conoidea. Taylor et al.’s (1993) anatomical study suggested a closer relationship of Clathurellinae, Conorbinae, Mangeliinae, Oenopotinae and Raphitominae to Conus than to other members of the family Turridae s.l. and their extension of Conidae included these turrid subfamilies. In our study, clade B, although weakly supported, corresponds to Taylor et al.'s (1993) family Conidae, thus supporting its monophyly.

Our study also revealed another weakly supported deep clade (clade A) that includes genera classified by Taylor et al. (1993) in three different families: Drilliidae, Terebridae and Turridae s.s. (consisting of Clavatulinae, Cochlespirinae, Crassispirinae, Turrinae and Zonulispirinae). Genera of the Drilliidae (clade 1) are included in clade C. This wellsupported clade also contains taxa of the Turridae s.s. (Crassispirinae and Comitas), and excludes the other taxa of the Turridae s.s. Consequently, Turridae s.s. are not monophyletic. Furthermore, according to Kantor (2006), the radula of Drilliidae is not fundamentally different from that of Turridae s.s.

Within clade A, the monophyly of the Terebridae is supported but its relationships with other clades of Turridae s.s. is not resolved. The strong support obtained for clade A0 (clade A without clade 9) indicates that Terebridae are closely related to Turridae s.s. Moreover, the increase of clade support from A to A0 suggests an artifact effect of clade 9 on the phylogenetic reconstruction, e.g., a long branch attraction effect with the outgroups. This phenomenon could be avoided by increasing the amount of diversity included in the analysis (Bergsten, 2005). A close relationship between Terebridae and Turridae s.s. had already been suggested by Cossmann (1896), and Powell (1942, 1966), based on the resemblance of the shells of Terebridae and of the clavatuline genus Pusionella. Based on this observation and the fossil record, Powell (1966) speculated that Terebridae were derived from the Clavatulinae. Our results suggest that Turridae s.s. could be closer to Terebridae than to Conidae, but the question of whether Terebridae is included in Turridae s.s. or is its sister group still remains unresolved.

\subsection{Towards a stabilized system for Conoidea}

The weak support of neogastropod molecular phylogenies available in literature is supposed to be the consequence of an early radiation of the group (Harasewych et al., 1997; Colgan et al., 2003, 2007). Genes used in those studies were not adequate to resolve the relationships between clades that emerged during this radiation. In our study, we used the same genes, albeit at a lower taxonomic level, but deeper nodes are not resolved either. In view of the fact that most subfamilies of Turridae s.l. were already present in the Eocene, Powell (1966) dated their divergence before the Upper Cretaceous (before 65MY). As for other animal groups (e.g., Strugnell et al., 2005; Fry et al., 2006), resolving phylogenetic relationships between those early divergences seems to require slow-evolving genes. In this perspective, nuclear coding genes, rarely used in mollusk phylogenies, could be useful to resolve early relationships within Conoidea as well as deeper relationships within gastropods. The taxonomic sampling used here allows an estimation of molecular variability within clades at each level: several genera are included in each subfamily, several subfamilies are included in each family, and most of the families defined by Taylor et al. (1993) are present. This strategy, where taxonomic sampling is hierarchically organized, is clearly required to discuss monophyly of each of those groups, and some problems are thus highlighted at each taxonomic level. 
However, even with a dataset of 57 genera, covering most of the previously recognized families and subfamilies of Conoidea, the present study only brings preliminary results. At genus level, these 57 genera represent only $17 \%$ of the 340 already described recent genera and it is further clear that the shell-based current taxonomic extension of many genera will not stand after molecular testing. At subfamily and family levels, although a large part of the conoidean diversity is represented in this study, the families Strictispiridae and Pseudomelatomidae, the subfamilies Zonulispirinae and Zemaciinae in Turridae s.s., the Pervicaciinae in Terebridae and the Oenopotinae in Conidae, are not part of our taxon sampling. The highly divergent clades found here in several subfamilies as previously defined demonstrate the need for further research in order to better restrict the taxonomic extensions of the already known subfamilies and probably formally name new subfamilies and/or tribes. Finally, at family level, new relationships are suggested. As a remake of the Conus story, it now appears that the long recognized family Terebridae does not stand alone apart from the rest of the Conoidea, but could be the sister-group or even part of the Turridae s.s.

\section{Acknowledgments}

We are grateful to Bertrand Richer de Forges, cruise leader of several deep-sea cruises of the Tropical Deep Sea Benthos programme on board R/V Alis, that generated the deep-sea samples used in this study. The Total Foundation supported the Panglao 2004 and Santo 2006 biodiversity surveys and Ellen Strong is thanked for her role in molecular sampling during these expeditions. We are also pleased to thank the staff of MNHN's " Service de Syste'matique Mole 'culaire” for technical facilities; the Consortium National de Recherche en Ge'nomique, Ge'noscope for the sequencing facilities; S. Gofas for collecting African taxa; Barbara Buge and Pierre Lozouet for the pictures; and P. Lopez, N. Vidal, P. Gaubert, A. Ware'n and E. Strong for constructive comments on, and improvements of, the manuscript. Y. Terryn and A. Kohn identified specimens of Terebridae and Conus, respectively. The authors thank two anonymous referees for very constructive comments on the manuscript.

\section{References}

Bergsten, J., 2005.Areviewof long-branch attraction. Cladistics 21, 163-193.

Bouchet, P., 1990. Turrid genera and mode of development: the use and abuse of protoconch morphology. Malacologia 32, 69-77.

Bouchet, P., Rocroi, J.-P., 2005. Classification and nomenclator of Gastropods families. Malacologia 47.

Bouchet, P., Waren, A., 1980. Revision of the north-east Atlantic bathyal and abyssal

Turridae (Mollusca, Gastropoda). J. Molluscan Stud. Suppl. 8, 1-119.

Chang, C.-K., 1995. Reevaluation of the classification of Turridae. Bull. Malacol. Taiwan 19, 49.

Chang, C.-K., 2001. Small Turrids of Taiwan. Thorsson, W.M., Taiwan.

Colgan, D.J., Ponder, W.F., Beacham, E., Macaranas, J., 2003. Gastropod phylogeny based on six fragments from four genes representing coding or non-coding and mitochondrial or nuclear DNA. Molluscan Res. 23, 123-148.

Colgan, D.J., Ponder, W.F., Beacham, E., Macaranas, J., 2007. Molecular phylogenetics of Caenogastropoda (Gastropoda: Mollusca). Mol. Phylogenet. Evol. 42, 717-737.

Cossmann, M., 1896. Essais de Paléoconchologie comparée, 2ème livraison. Paris.

Darlu, P., Tassy, P., 1993. La reconstruction phylogénétique. Concepts et méthodes. Masson, Paris.

Dayrat, B., Tillier, A., Lecointre, G., Tillier, S., 2001. New clades of Euthyneuran Gastropods (Mollusca) from 28S rRNA sequences. Mol. Phylogenet. Evol. 19, 225-235. 
Duda, T.F., Kohn, A.J., 2005. Species-level phylogeography and evolutionary history of the hyperdiverse marine gastropod genus Conus. Mol. Phylogenet. Evol. 34, 257-272.

Felsenstein, J., 1985. Confidence limits on phylogenies: an approach using the bootstrap. Evolution 39, 783-791.

Felsenstein, J., 2004. Inferring Phylogenies. Sinauer Associates, Sunderland.

Fischer, P., 1887. Manuel de conchyliologie et de paléontologie conchyliologique. F. Savy, Paris.

Folmer, O., Black, M., Hoeh, W., Lutz, R., Vrijenhoek, R., 1994. DNA primers for amplification of mitochondrial cytochrome c oxidase subunit I from diverse metazoan invertebrates. Mol. Mar. Biol. Biotechnol. 3, 294-299.

Fry, B.G., Vidal, N., Norman, J.A., Vonk, F.J., Scheib, H., Ramjan, S.F.R., Kuruppu, S., Fung, K., Hedges, S.B., Richardson, M.K., Hodgson, W.C., Ignjatovic, V., Summerhayes, R., Kochva, E., 2006. Early evolution of the venom system in lizards and snakes. Nature 439, 584-588.

Giribet, G., Carranza, S., Bagui, J., Riutort, M., Ribera, C., 1996. First molecular evidence for the existence of a Tardigrada + Arthropoda clade. Mol. Biol. Evol. 13, 76-84.

Guindon, S., Gascuel, O., 2003. A simple, fast, and accurate algorithm to estimate large phylogenies by maximum likelihood. Syst. Biol. 52, 696- 704.

Hall, T.A., 1999. BioEdit: a user-friendly biological sequence alignment editor and analysis program for Windows 95/98/NT. Nucleic Acids Symp. Ser. 41, 95-98.

Harasewych, M.G., Adamkewicz, S.L., Blake, J.A., Saudek, D., Spriggs, T., Bult, C.J., 1997. Neogastropod phylogeny: a molecular perspective. J. Molluscan Stud. 63, 327-351.

Hassouna, M., Michot, B., Bachellerie, J.-P., 1984. The complete nucleotide sequence of mouse 28SrRNA gene. Implications for the process of size increase of the large subunit rRNA of higher eukaryotes. Nucleic Acids Res. 12, 3563-3583.

Hebert, P.D.N., Cywinska, A., Ball, S.L., deWaard, J.R., 2003. Biological identifications through DNA Barcodes. Proc. R. Soc. Lond. B 270, 313-321.

Hedley, C., 1922. A revision of the Australian Turridae. Rec. Aust. Mus. 13, 213-359. Hillis, D.M., Bull, J.J., 1993. An empirical test of bootstrapping as a method for assessing confidence in phylogenetic analysis. Syst. Biol. 42, 182-192.

Huelsenbeck, J.P., Ronquist, F., Hall, B., 2001. MrBayes: Bayesian inference of phylogeny. Bioinformatics 17, 754-755.

Jovelin, R., Justine, J.-L., 2001. Phylogenetic relationships within the Polyopisthocotylean monogeneans (Plathyhelminthes) inferred from partial 28S rDNA sequences. Int. J. Parasitol. 31, 393- 401.

Kantor, Y.I., 2006. On the morphology and homology of the "central tooth" in the radula of Turrinae (Conoidea: Turridae). Ruthenica 16, 47-52.

Kantor, Y.I., Medinskaya, A.I., Taylor, J.D., 1997. Foregut anatomy and relationships of the Crassispirinae (Gastropoda, Conoidea). Bull. Nat. Hist. Mus. Lond. (Zool.) 63, 55-92.

Kantor, Y.I., Taylor, J.D., 1994. The foregut anatomy of Strictispira paxillus (Reeve, 1845) (Conoidea: Strictispiridae). J. Molluscan Stud. 60, 343-346.

Kilburn, R.N., 1983. Turridae (Mollusca: Gastropoda) of southern Africa and Mozambique. Part 1. Subfamily Turrinae. Natal Mus. Ann. 25, 549-585.

Kilburn, R.N., 1985. Turridae (Mollusca: Gastropoda) of southern Africa and Mozambique. Part 2. Subfamily Clavatulinae. Natal Mus. Ann. 26, 417-470.

Kilburn, R.N., 1986. Turridae (Mollusca: Gastropoda) of southern Africa and Mozambique. Part 3. Subfamily Borsoniinae. Natal Mus. Ann. 27, 633-720.

Kilburn, R.N., 1988. Turridae (Mollusca: Gastropoda) of southern Africa and Mozambique. Part 4. Subfamily Drilliinae, Crassispirinae and Strictispirinae. Natal Mus. Ann. 29, 167-320. 
Kilburn, R.N., 1989. Notes on Ptychobela and Brachytoma, with the description of a new species from Mozambique (Mollusca: Gastropoda: Turridae). Natal Mus. Ann. 30, 185-196. Kilburn, R.N., 1991. Turridae (Mollusca: Gastropoda) of southern Africa and Mozambique. Part 5. Subfamily Taraninae. Natal Mus. Ann. 32, 325-339.

Kilburn, R.N., 1992. Turridae (Mollusca: Gastropoda) of southern Africa and Mozambique. Part 6. Subfamily Mangeliinae, section 1. Natal Mus. Ann. 33, 461-575.

Kilburn, R.N., 1993. Turridae (Mollusca: Gastropoda) of southern Africa and Mozambique. Part 6. Subfamily Mangeliinae, section 2. Natal Mus. Ann. 34, 317-367.

Kilburn, R.N., 1994. Turridae [s.l.] (Mollusca: Gastropoda) of southern Africa and Mozambique. Part 7. Subfamily Crassispirinae, section 2. Natal Mus. Ann. 35, 177-228. Kilburn, R.N., 1995. Turridae (s.l.) of southern Africa and Mozambique (Mollusca: Gastropoda: Conoidea). Part 8. Conidae: subfamily Mangeliinae, section 3. Natal Mus. Ann. 36, 261-269.

Kilburn, R.N., 2004. The identities of Otitoma and Antimitra (Mollusca: Gastropoda: Conidae and Buccinidae). Afr. Invertebr. 45, 263-270.

Kohn, A.J., 1990. Tempo and mode of evolution in Conidae. Malacologia 32, 55-67. Mason-Gamer, R.J., Kellogg, E.A., 1996. Testing for phylogenetic conflict among molecular data sets in the tribe Triticeae (Graminae). Syst. Biol. 45, 524-545.

McLean, J.H., 1971. A revised classification of the family Turridae, with the proposal of new subfamilies, genera and subgenera from the Eastern pacific. Veliger 14, 114-130.

Medinskaya, A.I., 2002. Foregut anatomy of the Turrinae (Gastropoda, Conoidea, Turridae). Ruthenica 12, 135-159.

Medinskaya, A.I., Sysoev, A., 2003. The anatomy of Zemacies excelsa, with a description of a new subfamily of Turridae (Gastropoda, Conoidea). Ruthenica 13, 81-87.

Morrison, J.P.E., 1965. On the families of Turridae. In: The 31st Annual Meeting of the American Malacologial Union, pp. 1-2.

Okusu, A., Schwabe, E., Eernisse, D.J., Giribet, G., 2003. Towards a phylogeny of chitons (Mollusca, Polyplacophora) based on combined analysis of five molecular loci. Org. Divers. Evol. 3, 281-302.

Posada, D., Crandall, K.A., 2001. Selecting models of nucleotide substitution: an application to human immunodeficiency virus 1 (HIV-1). Mol. Biol. Evol. 18, 897-906.

Powell, A.W.B., 1942. The New-Zealand recent and fossil Mollusca of the family Turridae. With general notes on turrid nomenclature and systematics. Bull. Auckland Inst. Mus. 2, 1192.

Powell, A.W.B., 1966. The molluscan families Speightiidae ans Turridae. An evaluation of the valid taxa, both recent and fossil, with list of characteristic species. Bull. Auckland Inst. Mus. 5, 1-184.

Rosenberg, G., 1998. Reproducibility of results in phylogenetic analysis of mollusks: a reanalysis of the Taylor, Kantor and Sysoev (1193) data set for conoidean gastropods. Am. Malac. Bull. 14, 219-228.

Shimek, R.L., Kohn, A.J., 1981. Functional morphology and evolution of the toxoglossan radula. Malacologia 20, 423-438.

Shuto, T., 1983. New turrid taxa from the Australian waters. Mem. Fac. Sci. Kyushu Univ. Serie D Geol. 25, 16.

Soltis, P.S., Soltis, D.E., 2003. Applying the bootstrap in phylogeny reconstruction. Stat. Sci. 18, 256-267.

Strugnell, J., Norman, M., Jackson, J., Drummond, A.J., Cooper, A., 2005. Molecular phylogeny of coleoid cephalopods (Mollusca: Cephalopoda) using a multigene approach; the effect of data partitioning on resolving phylogenies in a bayesian framework.Mol. Phylogenet. Evol. 37, 426-441. 
546 Swofford, D.L., 2002. PAUP*. Phylogenetic Analysis Using Parsimony* and Other Methods.

547 Sinauer Associates, Sunderland.

548 Sysoev, A., Bouchet, P., 1996. Taxonomic reevaluation of Gemmuloborsonia Shuto, 1989

549 (Gastropoda: Conoidea), with a description of recent deep-water species. J. Molluscan Stud.

550 62, 75-87.

551 Sysoev, A., Kantor, Y.I., 1990. A new genus and species of “Cochlespira-like” turrids. Apex

552 5, 1-6.

553 Taylor, J.D., 1994. Foregut anatomy of the larger species of Turrinae, Clavatulinae and

554 Crassispirinae (Gastropoda: Conoidea) from Hong- Kong. In: Third International Workshop

555 on the Malacofauna of Hong-Kong and Southern China.

556 Taylor, J.D., Kantor, Y.I., Sysoev, A.V., 1993. Foregut anatomy, feedings mechanisms and

557 classification of the Conoidea (= Toxoglossa)(Gastropoda). Bull. Nat. Hist. Mus. Lond. 59,

558 125-170.

559 Terryn, Y., 2007. A Collectors Guide to Recent Terebridae (Mollusca: Neogastropoda).

560 ConchBooks, Hackenheim. Thiele, J., 1929. Handbuch der systematischen weichtierkunde. G.

561 Fischer, Jena.

562 Tippet, D.L., Tucker, J.K., 1995. Taxonomic notes on Kenyonia Brazier and Conopleura

563 Hinds (Gastropoda: Conoidea). Nautilus 108, 37-38.

564 Tucker, J.K., 2004. Catalogue of recent and fossil turrids (Mollusca: Gastropoda). Zootaxa

565 682, 1-1295.

566 Wenz, W., 1938-1944. Teil 1: Allgemeiner Teil und Prosobranchia. In: Schindewolf, O.H.

567 (Ed.), Handbuch de paläozoologie, Band 6, Gastropoda. Borntraeger, Berlin.

568 Wiens, J.J., 1998. Does adding characters with missing data increase or decrease phylogenetic

569 accuracy? Syst. Biol. 47, 625-640.

570 Zander, R.H., 2004. Minimal values for reliability of bootstrap and Jackknife proportions,

571 Decay index, and bayesian posterior probability. PhyloInformatics 2, 1-13.

572 
Table 1: Evolution of Conoidea classification.

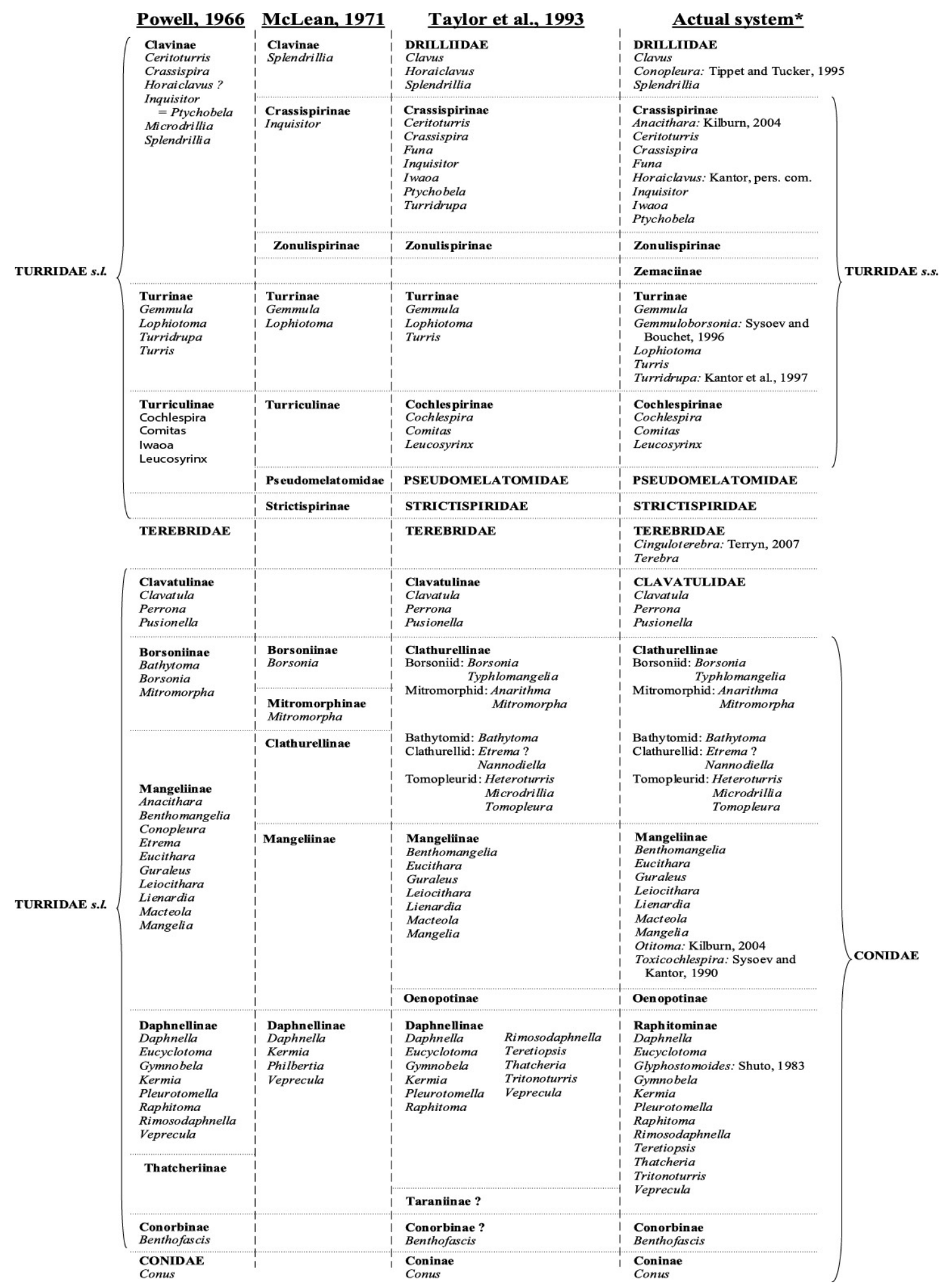

History of conoidean classification and position of the genera included in the present dataset in the classifications of Powell (1966), McLean (1971) and Taylor et al. (1993). Subfamilies are in bold, families in bold and capital. *Recent modifications proposed since the classification of Taylor et al. (1993) (details given for each genus), resulting in the actual system used as a basis for our discussion. (See above-mentioned references for further information). 


\begin{tabular}{|c|c|c|c|c|c|c|c|c|c|c|}
\hline ID & Cruise & Station ID & Coordinates, depth & Genus (or species) identification & COI & $28 \mathrm{~S}$ & $18 \mathrm{~S}$ & H3 & \multicolumn{2}{|c|}{ Clades } \\
\hline $17700^{*}$ & BOA 1 & CP2462 & $\begin{array}{c}6^{\circ} 37.5^{\prime} \mathrm{S}, 167^{\circ} 57.4^{\prime} \mathrm{E}, 618- \\
641 \mathrm{~m} \\
\end{array}$ & Bathytoma Harris and Burrows, 1891 & $\mathrm{x}$ & $\mathrm{x}$ & $\mathrm{x}$ & $\mathrm{x}$ & 20 & B \\
\hline $17701^{*}$ & BOA 1 & CP2432 & $\begin{array}{l}14^{\circ} 59.7^{\prime} \mathrm{S}, 166^{\circ} 55.0^{\prime} \text { E, 630- } \\
705 \mathrm{~m}\end{array}$ & Leucosyrinx Dall, 1889 & $\mathrm{x}$ & $\mathrm{x}$ & $\mathrm{x}$ & $\mathrm{x}$ & 9 & A \\
\hline 17702 & BOA 1 & CP2432 & $\begin{array}{c}14^{\circ} 59.7^{\prime} \mathrm{S}, 166^{\circ} 55.0^{\prime} \mathrm{E}, 630- \\
705 \mathrm{~m} \\
\end{array}$ & Leucosyrinx Dall, 1889 & $\mathrm{x}$ & $\mathrm{x}$ & $\mathrm{x}$ & $\mathrm{x}$ & 9 & A \\
\hline $17754^{*}$ & Panglao 2004 & $\mathrm{R} 42$ & $9^{\circ} 37.1^{\prime} \mathrm{N}, 123^{\circ} 52.6^{\prime} \mathrm{E}, 8-22 \mathrm{~m}$ & Turris Roding, 1798 & $\mathrm{x}$ & $\mathrm{x}$ & $\mathrm{x}$ & $\mathrm{x}$ & 5 & A \\
\hline $17755^{\star}$ & Panglao 2004 & L46 & $9^{\circ} 30.9^{\prime} \mathrm{N}, 123^{\circ} 41.2^{\prime} \mathrm{E}, 90-110 \mathrm{~m}$ & Crassispira Swainson, 1840 & $\mathrm{x}$ & $\mathrm{x}$ & $\mathrm{x}$ & $\mathrm{x}$ & $\begin{array}{l}2, \\
\mathrm{C}\end{array}$ & A \\
\hline 17829 & Angola & Ilha de Luanda & $8^{\circ} 78^{\prime} \mathrm{S}, 13.23^{\prime} \mathrm{E}, 40-60 \mathrm{~m}$ & Clavatula Lamarck, 1801 & $\mathrm{x}$ & & & & 22 & A \\
\hline 17830 & Angola & Cacuaco & $10^{\circ} 51^{\prime} \mathrm{S}, 14^{\circ} 23^{\prime} \mathrm{E}, 5-10 \mathrm{~m}$ & Pusionella Gray, 1847 & $\mathrm{x}$ & & & & 22 & A \\
\hline 17831 & Angola & Cacuaco & $10^{\circ} 51^{\prime} \mathrm{S}, 14^{\circ} 23^{\prime} \mathrm{E}, 5-10 \mathrm{~m}$ & Pusionella Gray, 1847 & $\mathrm{x}$ & & & & 22 & A \\
\hline 17832 & Cameroun & Victoria & $3^{\circ} 54^{\prime} \mathrm{N}, 9^{\circ} 08^{\prime} \mathrm{E}, 34-37 \mathrm{~m}$ & Pusionella Gray, 1847 & $\mathrm{x}$ & & & & 22 & A \\
\hline 17833 & Angola & Mocamedes & $15^{\circ} 14^{\prime} \mathrm{S}, 12^{\circ} 29^{\prime} \mathrm{E}, 50 \mathrm{~m}$ & Perrona Schumacher, 1817 & $\mathrm{x}$ & & & & 22 & A \\
\hline 17834 & Gabon & Port-Gentil & $1^{\circ} 17^{\prime} \mathrm{S}, 11^{\circ} 53^{\prime} \mathrm{Em}$ & Pusionella Gray, 1847 & $\mathrm{x}$ & & & & 22 & A \\
\hline $17835^{*}$ & BOA 1 & CP2462 & $\begin{array}{c}16^{\circ} 37.5^{\prime} \mathrm{S}, 167^{\circ} 57.4^{\prime} \mathrm{E}, 618- \\
641 \mathrm{~m}\end{array}$ & Benthomangelia Thiele, 1925 & $\mathrm{x}$ & $\mathrm{x}$ & $\mathrm{x}$ & $\mathrm{x}$ & 17 & $\mathrm{~B}$ \\
\hline 17836 & BOA 1 & CP2462 & $\begin{array}{c}16^{\circ} 37.5^{\prime} \mathrm{S}, 167^{\circ} 57.4^{\prime} \text { E, 618- } \\
641 \mathrm{~m}\end{array}$ & Rimosodaphnella Cossmann, 1915 & $\mathrm{x}$ & $\mathrm{x}$ & $\mathrm{x}$ & $\mathrm{x}$ & 10 & B \\
\hline 17837 & EBISCO & DW2547 & $21^{\circ} 06^{\prime} \mathrm{S}, 158^{\circ} 36^{\prime} \mathrm{E}, 356-438 \mathrm{~m}$ & Inquisitor Hedley, 1918 & $\mathrm{x}$ & $\mathrm{x}$ & $\mathrm{x}$ & $\mathrm{x}$ & $\begin{array}{l}2, \\
\text { C }\end{array}$ & A \\
\hline 17838 & EBISCO & DW2533 & $22^{\circ} 18^{\prime} \mathrm{S}, 159^{\circ} 28^{\prime} \mathrm{E}, 360-370 \mathrm{~m}$ & Gemmula Weinkauff, 1875 & $\mathrm{x}$ & $\mathrm{x}$ & $\mathrm{x}$ & $\mathrm{x}$ & 5 & A \\
\hline $17839^{*}$ & EBISCO & CP2557 & $21^{\circ} 07^{\prime} \mathrm{S}, 158^{\circ} 30^{\prime} \mathrm{E}, 800-923 \mathrm{~m}$ & Borsonia Bellardi, 1839 & $\mathrm{x}$ & $\mathrm{x}$ & $\mathrm{x}$ & $\mathrm{x}$ & 16 & $\mathrm{~B}$ \\
\hline $17840^{*}$ & EBISCO & DW2631 & $21^{\circ} 03^{\prime} \mathrm{S}, 160^{\circ} 44^{\prime} \mathrm{E}, 372-404 \mathrm{~m}$ & Horaiclavus Oyama, 1954 & $\mathrm{x}$ & $\mathrm{x}$ & $\mathrm{x}$ & $\mathrm{x}$ & 7 & A \\
\hline 17841 & EBISCO & СР2648 & $21^{\circ} 32^{\prime} \mathrm{S}, 162^{\circ} 30^{\prime} \mathrm{E}, 750-458 \mathrm{~m}$ & Gymnobela Verrill, 1884 & $\mathrm{x}$ & $\mathrm{x}$ & $\mathrm{x}$ & $\mathrm{x}$ & 10 & $\mathrm{~B}$ \\
\hline $17842^{*}$ & EBISCO & DW2553 & $21^{\circ} 03^{\prime} \mathrm{S}, 158^{\circ} 36^{\prime} \mathrm{E}, 352-370 \mathrm{~m}$ & Cochlespira Conrad, 1865 & $\mathrm{x}$ & $\mathrm{x}$ & $\mathrm{x}$ & & 8 & A \\
\hline 17843 & EBISCO & DW2522 & $22^{\circ} 46^{\prime} \mathrm{S}, 159^{\circ} 21^{\prime} \mathrm{E}, 310-318 \mathrm{~m}$ & Funa Kilburn, 1988 & $\mathrm{x}$ & $\mathrm{x}$ & $\mathrm{x}$ & $\mathrm{x}$ & $\begin{array}{l}2, \\
\text { C }\end{array}$ & A \\
\hline 17844 & EBISCO & CP2645 & $20^{\circ} 58^{\prime} \mathrm{S}, 160^{\circ} 58^{\prime} \mathrm{E}, 641-652 \mathrm{~m}$ & Gymnobela Verrill, 1884 & $\mathrm{x}$ & $\mathrm{x}$ & $\mathrm{x}$ & $\mathrm{x}$ & 10 & $\mathrm{~B}$ \\
\hline 17845 & EBISCO & CP2651 & $21^{\circ} 29^{\prime} \mathrm{S}, 162^{\circ} 36^{\prime} \mathrm{E}, 883-957 \mathrm{~m}$ & Teretiopsis Kantor and Sysoev, 1989 & $\mathrm{x}$ & $\mathrm{x}$ & $\mathrm{x}$ & $\mathrm{x}$ & 10 & B \\
\hline $17846^{*}$ & EBISCO & СР2600 & $19^{\circ} 38^{\prime} \mathrm{S}, 158^{\circ} 46^{\prime} \mathrm{E}, 603-630 \mathrm{~m}$ & Leucosyrinx Dall, 1889 & $\mathrm{x}$ & $\mathrm{x}$ & $\mathrm{x}$ & $\mathrm{x}$ & $\begin{array}{l}3, \\
\mathrm{C}\end{array}$ & A \\
\hline $17847^{*}$ & EBISCO & DW2617 & $20^{\circ} 06^{\prime} \mathrm{S}, 160^{\circ} 22^{\prime} \mathrm{E}, 427-505 \mathrm{~m}$ & Splendrillia Hedley, 1922 & $\mathrm{x}$ & $\mathrm{x}$ & $\mathrm{x}$ & $\mathrm{x}$ & $\begin{array}{l}1, \\
\mathrm{C}\end{array}$ & A \\
\hline 17848 & EBISCO & DW2625 & $20^{\circ} 05^{\prime} \mathrm{S}, 160^{\circ} 19^{\prime} \mathrm{E}, 627-741 \mathrm{~m}$ & Pleurotomella Verrill, 1873 & $\mathrm{x}$ & $\mathrm{x}$ & $\mathrm{x}$ & $\mathrm{x}$ & 10 & $\mathrm{~B}$ \\
\hline $17849^{*}$ & EBISCO & DW2619 & $20^{\circ} 06^{\prime} \mathrm{S}, 160^{\circ} 23^{\prime} \mathrm{E}, 490-550 \mathrm{~m}$ & cf. Gemmuloborsonia Shuto, 1989 & $\mathrm{x}$ & $\mathrm{x}$ & $\mathrm{x}$ & $\mathrm{x}$ & & A \\
\hline 17850 & EBISCO & DW2607 & $19^{\circ} 33^{\prime} \mathrm{S}, 158^{\circ} 40^{\prime} \mathrm{E}, 400-413 \mathrm{~m}$ & Turridrupa Hedley, 1922 & $\mathrm{x}$ & $\mathrm{x}$ & $\mathrm{x}$ & $\mathrm{x}$ & 5 & A \\
\hline 17851 & EBISCO & DW2625 & $20^{\circ} 05^{\prime} \mathrm{S}, 160^{\circ} 19^{\prime} \mathrm{E}, 627-741 \mathrm{~m}$ & Inquisitor Hedley, 1918 & $\mathrm{x}$ & $\mathrm{x}$ & $\mathrm{x}$ & $\mathrm{x}$ & $\begin{array}{l}2, \\
\mathrm{C}\end{array}$ & A \\
\hline 17852 & EBISCO & DW2625 & $20^{\circ} 05^{\prime} \mathrm{S}, 160^{\circ} 19^{\prime} \mathrm{E}, 627-741 \mathrm{~m}$ & Gemmula Weinkauff, 1875 & $\mathrm{x}$ & $\mathrm{x}$ & $\mathrm{x}$ & $\mathrm{x}$ & 5 & $\mathrm{~A}$ \\
\hline $17853^{*}$ & EBISCO & DW2629 & $21^{\circ} 06^{\prime} \mathrm{S}, 160^{\circ} 46^{\prime} \mathrm{E}, 569-583 \mathrm{~m}$ & Heteroturris Powell, 1967 & $\mathrm{x}$ & $\mathrm{x}$ & $\mathrm{x}$ & $\mathrm{x}$ & 18 & $\mathrm{~B}$ \\
\hline $17855^{*}$ & Norfolk 2 & DW2155 & $22^{\circ} 52^{\prime} \mathrm{S}, 167^{\circ} 13^{\prime} \mathrm{E}, 453-455 \mathrm{~m}$ & Benthofascis Iredale, 1936 & & $\mathrm{x}$ & $\mathrm{x}$ & $\mathrm{x}$ & & $\mathrm{B}$ \\
\hline 17857 & EBISCO & CP2551 & $21^{\circ} 06^{\prime} \mathrm{S}, 158^{\circ} 35^{\prime} \mathrm{E}, 637-650 \mathrm{~m}$ & Bathytoma Harris and Burrows, 1891 & $\mathrm{x}$ & $\mathrm{x}$ & $\mathrm{x}$ & $\mathrm{x}$ & 20 & B \\
\hline 17858 & Panglao 2004 & S12 & $9^{\circ} 29.4^{\prime} \mathrm{N}, 123^{\circ} 56.0^{\prime} \mathrm{E}, 6-8 \mathrm{~m}$ & Clavus Monfort, 1810 & $\mathrm{x}$ & $\mathrm{x}$ & $\mathrm{x}$ & $\mathrm{x}$ & $\begin{array}{l}1, \\
\mathrm{C}\end{array}$ & $\mathrm{A}$ \\
\hline 17859 & Panglao 2004 & S12 & $9^{\circ} 29.4^{\prime} \mathrm{N}, 123^{\circ} 56.0^{\prime} \mathrm{E}, 6-8 \mathrm{~m}$ & Turridrupa Hedley, 1922 & $\mathrm{x}$ & $\mathrm{x}$ & $\mathrm{x}$ & $\mathrm{x}$ & 5 & A \\
\hline 17860 & Panglao 2004 & R44 & $9^{\circ} 33.3^{\prime} \mathrm{N}, 123^{\circ} 43.9^{\prime} \mathrm{E}, 2 \mathrm{~m}$ & Lophiotoma Casey, 1904 & $\mathrm{x}$ & $\mathrm{x}$ & $\mathrm{x}$ & $\mathrm{x}$ & 5 & B \\
\hline 17861 & Panglao 2004 & B14 & $9^{\circ} 38.5^{\prime} \mathrm{N}, 123^{\circ} 49.2^{\prime} \mathrm{E}, 2-4 \mathrm{~m}$ & Kermia Oliver, 1915 & $\mathrm{x}$ & $\mathrm{x}$ & $\mathrm{x}$ & $\mathrm{x}$ & 10 & $\mathrm{~B}$ \\
\hline 17862 & Panglao 2004 & $\mathrm{~T} 10$ & $9^{\circ} 33.4^{\prime} \mathrm{N}, 123^{\circ} 49.6^{\prime} \mathrm{E}, 117-124 \mathrm{~m}$ & Gemmula Weinkauff, 1875 & $\mathrm{x}$ & $\mathrm{x}$ & $\mathrm{x}$ & $\mathrm{x}$ & 5 & A \\
\hline 17863 & Panglao 2004 & B16 & $9^{\circ} 37.6^{\prime} \mathrm{N}, 123^{\circ} 47.3^{\prime} \mathrm{E}, 20 \mathrm{~m}$ & Macteola Hedley, 1918 & $\mathrm{x}$ & $\mathrm{x}$ & $\mathrm{x}$ & $\mathrm{x}$ & 11 & $\mathrm{~B}$ \\
\hline 17864 & Panglao 2004 & S18 & $9^{\circ} 35.7^{\prime} \mathrm{N}, 123^{\circ} 44.4^{\prime} \mathrm{E}, 0-2 \mathrm{~m}$ & cf. Guraleus Hedley, 1918 & $\mathrm{x}$ & $\mathrm{x}$ & $\mathrm{x}$ & $\mathrm{x}$ & 11 & $\mathrm{~B}$ \\
\hline 17865 & Panglao 2004 & P2 & $9^{\circ} 39^{\prime} \mathrm{N}, 123^{\circ} 44^{\prime} \mathrm{E}, 400 \mathrm{~m}$ & Bathytoma Harris and Burrows, 1891 & $\mathrm{x}$ & $\mathrm{x}$ & $\mathrm{x}$ & $\mathrm{x}$ & 20 & $\mathrm{~B}$ \\
\hline $17866^{*}$ & Panglao 2004 & S19 & $9^{\circ} 42.1^{\prime} \mathrm{N}, 123^{\circ} 51.4^{\prime} \mathrm{E}, 3-4 \mathrm{~m}$ & Mangelia Risso, 1826 & $\mathrm{x}$ & $\mathrm{x}$ & $\mathrm{x}$ & $\mathrm{x}$ & 11 & $\mathrm{~B}$ \\
\hline 17867 & Panglao 2004 & B19 & $9^{\circ} 29.4^{\prime} \mathrm{N}, 123^{\circ} 56.0^{\prime} \mathrm{E}, 17 \mathrm{~m}$ & Borsonia Bellardi, 1839 & $\mathrm{x}$ & $\mathrm{x}$ & $\mathrm{x}$ & $\mathrm{x}$ & 16 & B \\
\hline 17868 & Panglao 2004 & B19 & $9^{\circ} 29.4^{\prime} \mathrm{N}, 123^{\circ} 56.0^{\prime} \mathrm{E}, 17 \mathrm{~m}$ & Anacithara Hedley, 1922 & $\mathrm{x}$ & $\mathrm{x}$ & $\mathrm{x}$ & $\mathrm{x}$ & 7 & A \\
\hline 17869 & Panglao 2004 & S21 & $9^{\circ} 41.7^{\prime} \mathrm{N}, 123^{\circ} 50.9^{\prime} \mathrm{E}, 4-12 \mathrm{~m}$ & Etrema Hedley, 1918 & $\mathrm{x}$ & $\mathrm{x}$ & $\mathrm{x}$ & $\mathrm{x}$ & 12 & $\mathrm{~B}$ \\
\hline 17870 & Panglao 2004 & $\mathrm{~S} 25$ & $9^{\circ} 41.5^{\prime} \mathrm{N}, 123^{\circ} 51.0^{\prime} \mathrm{E}, 21 \mathrm{~m}$ & Otitoma Jousseaume, 1898 & $\mathrm{x}$ & $\mathrm{x}$ & $\mathrm{x}$ & $\mathrm{x}$ & $\begin{array}{l}2, \\
\text { C }\end{array}$ & A \\
\hline 17871 & Panglao 2004 & S26 & $9^{\circ} 41.5^{\prime} \mathrm{N}, 123^{\circ} 51.0^{\prime} \mathrm{E}, 21 \mathrm{~m}$ & Kermia Oliver, 1915 & $\mathrm{x}$ & $\mathrm{x}$ & $\mathrm{x}$ & $\mathrm{x}$ & 10 & B \\
\hline
\end{tabular}




\begin{tabular}{|c|c|c|c|c|c|c|c|c|c|c|}
\hline 17872 & Panglao 2004 & S26 & $9^{\circ} 41.5^{\prime} \mathrm{N}, 123^{\circ} 51.0^{\prime} \mathrm{E}, 21 \mathrm{~m}$ & Macteola Hedley, 1918 & $\mathrm{x}$ & $\mathrm{x}$ & $\mathrm{x}$ & $\mathrm{x}$ & 11 & $\mathrm{~B}$ \\
\hline 17873 & Panglao 2004 & $\mathrm{~T} 26$ & $9^{\circ} 43.3^{\prime} \mathrm{N}, 123^{\circ} 48.8^{\prime} \mathrm{E}, 123-135 \mathrm{~m}$ & Guraleus Hedley, 1918 & $\mathrm{x}$ & $\mathrm{x}$ & $\mathrm{x}$ & $\mathrm{x}$ & 11 & $\mathrm{~B}$ \\
\hline 17874 & Panglao 2004 & $\mathrm{~T} 26$ & $9^{\circ} 43.3^{\prime} \mathrm{N}, 123^{\circ} 48.8^{\prime} \mathrm{E}, 123-135 \mathrm{~m}$ & Guraleus Hedley, 1918 & $\mathrm{x}$ & $\mathrm{x}$ & $\mathrm{x}$ & $\mathrm{x}$ & 11 & $\mathrm{~B}$ \\
\hline $17875^{\star}$ & Panglao 2004 & T26 & $9^{\circ} 43.3^{\prime} \mathrm{N}, 123^{\circ} 48.8^{\prime} \mathrm{E}, 123-135 \mathrm{~m}$ & Tomopleura Casey, 1924 & $\mathrm{x}$ & $\mathrm{x}$ & $\mathrm{x}$ & $\mathrm{x}$ & 14 & $\mathrm{~B}$ \\
\hline 17876 & Panglao 2004 & B21 & $9^{\circ} 37.2^{\prime} \mathrm{N}, 123^{\circ} 46.4^{\prime} \mathrm{E}, 20-21 \mathrm{~m}$ & Lienardia Jousseaume, 1928 & $\mathrm{x}$ & $\mathrm{x}$ & $\mathrm{x}$ & $\mathrm{x}$ & 12 & $\mathrm{~B}$ \\
\hline $17877^{*}$ & Panglao 2004 & B21 & $9^{\circ} 37.2^{\prime} \mathrm{N}, 123^{\circ} 46.4^{\prime} \mathrm{E}, 20-21 \mathrm{~m}$ & Mitromorpha Carpenter, 1865 & $\mathrm{x}$ & $\mathrm{x}$ & $\mathrm{x}$ & $\mathrm{x}$ & 13 & $\mathrm{~B}$ \\
\hline 17878 & Panglao 2004 & B25 & $9^{\circ} 29.4^{\prime} \mathrm{N}, 123^{\circ} 56.1^{\prime} \mathrm{E}, 16 \mathrm{~m}$ & Kermia Oliver, 1915 & $\mathrm{x}$ & $\mathrm{x}$ & $\mathrm{x}$ & $\mathrm{x}$ & 10 & $\mathrm{~B}$ \\
\hline 17879 & Panglao 2004 & T32 & $9^{\circ} 36.4^{\prime} \mathrm{N}, 123^{\circ} 53.8^{\prime} \mathrm{E}, 60-62 \mathrm{~m}$ & Inquisitor Hedley, 1918 & $\mathrm{x}$ & $\mathrm{x}$ & $\mathrm{x}$ & $\mathrm{x}$ & $\begin{array}{l}2, \\
\mathrm{C}\end{array}$ & $\mathrm{A}$ \\
\hline 17880 & Panglao 2004 & L46 & $9^{\circ} 30.9^{\prime} \mathrm{N}, 123^{\circ} 41.2^{\prime} \mathrm{E}, 90-110 \mathrm{~m}$ & Kermia Oliver, 1915 & $\mathrm{x}$ & $\mathrm{x}$ & $\mathrm{x}$ & $\mathrm{x}$ & 10 & $\mathrm{~B}$ \\
\hline 17881 & Panglao 2004 & L46 & $9^{\circ} 30.9^{\prime} \mathrm{N}, 123^{\circ} 41.2^{\prime} \mathrm{E}, 90-110 \mathrm{~m}$ & Daphnella Hinds, 1844 & $\mathrm{x}$ & $\mathrm{x}$ & $\mathrm{x}$ & $\mathrm{x}$ & 10 & $\mathrm{~B}$ \\
\hline $17882^{*}$ & Panglao 2004 & L46 & $9^{\circ} 30.9^{\prime} \mathrm{N}, 123^{\circ} 41.2^{\prime} \mathrm{E}, 90-110 \mathrm{~m}$ & Raphitoma Bellardi, 1848 & $\mathrm{x}$ & $\mathrm{x}$ & $\mathrm{x}$ & $\mathrm{x}$ & 10 & $\mathrm{~B}$ \\
\hline 17883 & Panglao 2004 & L46 & $9^{\circ} 30.9^{\prime} \mathrm{N}, 123^{\circ} 41.2^{\prime} \mathrm{E}, 90-110 \mathrm{~m}$ & Veprecula Melvill, 1917 & $\mathrm{x}$ & $\mathrm{x}$ & $\mathrm{x}$ & $\mathrm{x}$ & 10 & $\mathrm{~B}$ \\
\hline 17884 & Panglao 2004 & L46 & $9^{\circ} 30.9^{\prime} \mathrm{N}, 123^{\circ} 41.2^{\prime} \mathrm{E}, 90-110 \mathrm{~m}$ & Leiocithara Hedley, 1922 & $\mathrm{x}$ & $\mathrm{x}$ & $\mathrm{x}$ & $\mathrm{x}$ & 11 & $\mathrm{~B}$ \\
\hline 17885 & Panglao 2004 & T36 & $9^{\circ} 29.3^{\prime} \mathrm{N}, 123^{\circ} 51.5^{\prime} \mathrm{E}, 95-128 \mathrm{~m}$ & Ceritoturris Dall, 1924 & $\mathrm{x}$ & $\mathrm{x}$ & $\mathrm{x}$ & $\mathrm{x}$ & 7 & $\mathrm{~A}$ \\
\hline 17886 & Panglao 2004 & T36 & $9^{\circ} 29.3^{\prime} \mathrm{N}, 123^{\circ} 51.5^{\prime} \mathrm{E}, 95-128 \mathrm{~m}$ & Splendrillia Hedley, 1922 & $\mathrm{x}$ & $\mathrm{x}$ & $\mathrm{x}$ & $\mathrm{x}$ & $\begin{array}{l}1, \\
\text { C }\end{array}$ & A \\
\hline 17887 & Panglao 2004 & T36 & $9^{\circ} 29.3^{\prime} \mathrm{N}, 123^{\circ} 51.5^{\prime} \mathrm{E}, 95-128 \mathrm{~m}$ & Microdrillia Casey, 1903 & $\mathrm{x}$ & $\mathrm{x}$ & $\mathrm{x}$ & $\mathrm{x}$ & 18 & $\mathrm{~B}$ \\
\hline 17888 & Panglao 2004 & T36 & $9^{\circ} 29.3^{\prime} \mathrm{N}, 123^{\circ} 51.5^{\prime} \mathrm{E}, 95-128 \mathrm{~m}$ & Ceritoturris Dall, 1924 & $\mathrm{x}$ & $\mathrm{x}$ & $\mathrm{x}$ & $\mathrm{x}$ & 7 & A \\
\hline 17889 & Panglao 2004 & $\mathrm{~T} 41$ & $9^{\circ} 29.7^{\prime} \mathrm{N}, 123^{\circ} 50.2^{\prime} \mathrm{E}, 110-112 \mathrm{~m}$ & Conopleura Hinds, 1844 & $\mathrm{x}$ & $\mathrm{x}$ & $\mathrm{x}$ & $\mathrm{x}$ & $\begin{array}{l}1, \\
\mathrm{C}\end{array}$ & A \\
\hline 17890 & Panglao 2004 & L49 & $9^{\circ} 36.5^{\prime} \mathrm{N}, 123^{\circ} 45.3^{\prime} \mathrm{E}, 90 \mathrm{~m}$ & Raphitoma Bellardi, 1848 & $\mathrm{x}$ & $\mathrm{x}$ & $\mathrm{x}$ & $\mathrm{x}$ & 10 & $\mathrm{~B}$ \\
\hline 17891 & Panglao 2004 & T39 & $9^{\circ} 30.1^{\prime} \mathrm{N}, 123^{\circ} 50.4^{\prime} \mathrm{E}, 100-138 \mathrm{~m}$ & cf. Tritonoturris Dall, 1924 & $\mathrm{x}$ & $\mathrm{x}$ & $\mathrm{x}$ & $\mathrm{x}$ & 10 & $\mathrm{~B}$ \\
\hline 17892 & Panglao 2004 & T39 & $9^{\circ} 30.1^{\prime} \mathrm{N}, 123^{\circ} 50.4^{\prime} \mathrm{E}, 100-138 \mathrm{~m}$ & cf. Glyphostomoides Shuto, 1983 & $\mathrm{x}$ & $\mathrm{x}$ & $\mathrm{x}$ & $\mathrm{x}$ & 10 & $\mathrm{~B}$ \\
\hline 17893 & Panglao 2004 & $\mathrm{~T} 41$ & $9^{\circ} 29.7^{\prime} \mathrm{N}, 123^{\circ} 50.2^{\prime} \mathrm{E}, 110-112 \mathrm{~m}$ & cf. Mitromorpha Carpenter, 1865 & $\mathrm{x}$ & $\mathrm{x}$ & $\mathrm{x}$ & $\mathrm{x}$ & 13 & $\mathrm{~B}$ \\
\hline 17894 & Panglao 2004 & B7 & $9^{\circ} 35.9^{\prime} \mathrm{N}, 123^{\circ} 51.8^{\prime} \mathrm{E}, 4-30 \mathrm{~m}$ & Lienardia Jousseaume, 1928 & $\mathrm{x}$ & $\mathrm{x}$ & $\mathrm{x}$ & $\mathrm{x}$ & 12 & $\mathrm{~B}$ \\
\hline 17895 & Panglao 2004 & D5 & $9^{\circ} 33.6^{\prime} \mathrm{N}, 123^{\circ} 43.5^{\prime} \mathrm{E}, 0-3 \mathrm{~m}$ & Inquisitor Hedley, 1918 & $\mathrm{x}$ & $\mathrm{x}$ & $\mathrm{x}$ & $\mathrm{x}$ & $\begin{array}{l}2, \\
\mathrm{C}\end{array}$ & $\mathrm{A}$ \\
\hline 17896 & Panglao 2004 & D5 & $9^{\circ} 33.6^{\prime} \mathrm{N}, 123^{\circ} 43.5^{\prime} \mathrm{E}, 0-3 \mathrm{~m}$ & Eucithara Fischer, 1883 & $\mathrm{x}$ & $\mathrm{x}$ & $\mathrm{x}$ & $\mathrm{x}$ & 11 & $\mathrm{~B}$ \\
\hline $17897^{*}$ & Panglao 2004 & B8 & $9^{\circ} 37.1^{\prime} \mathrm{N}, 123^{\circ} 46.1^{\prime} \mathrm{E}, 3 \mathrm{~m}$ & Lienardia Jousseaume, 1928 & $\mathrm{x}$ & $\mathrm{x}$ & $\mathrm{x}$ & $\mathrm{x}$ & 12 & $\mathrm{~B}$ \\
\hline 17898 & Panglao 2004 & B8 & $9^{\circ} 37.1^{\prime} \mathrm{N}, 123^{\circ} 46.1^{\prime} \mathrm{E}, 3 \mathrm{~m}$ & Mitromorpha Carpenter, 1865 & $\mathrm{x}$ & $\mathrm{x}$ & $\mathrm{x}$ & $\mathrm{x}$ & 13 & $\mathrm{~B}$ \\
\hline 17899 & Panglao 2004 & B8 & $9^{\circ} 37.1^{\prime} \mathrm{N}, 123^{\circ} 46.1^{\prime} \mathrm{E}, 3 \mathrm{~m}$ & Eucithara Fischer, 1883 & $\mathrm{x}$ & $\mathrm{x}$ & $\mathrm{x}$ & $\mathrm{x}$ & 11 & $\mathrm{~B}$ \\
\hline 17900 & Panglao 2004 & B8 & $9^{\circ} 37.1^{\prime} \mathrm{N}, 123^{\circ} 46.1^{\prime} \mathrm{E}, 3 \mathrm{~m}$ & Eucithara Fischer, 1883 & $\mathrm{x}$ & $\mathrm{x}$ & $\mathrm{x}$ & $\mathrm{x}$ & 11 & $\mathrm{~B}$ \\
\hline 17901 & Panglao 2004 & S5 & $9^{\circ} 37.1^{\prime} \mathrm{N}, 123^{\circ} 46.1^{\prime} \mathrm{E}, 2-4 \mathrm{~m}$ & Anarithma Iredale, 1916 & $\mathrm{x}$ & $\mathrm{x}$ & $\mathrm{x}$ & $\mathrm{x}$ & 13 & B \\
\hline 17902 & Panglao 2004 & S6 & $9^{\circ} 38.5^{\prime} \mathrm{N}, 123^{\circ} 49.2^{\prime} \mathrm{E}, 1-4 \mathrm{~m}$ & Clavus Monfort, 1810 & $\mathrm{x}$ & $\mathrm{x}$ & $\mathrm{x}$ & $\mathrm{x}$ & $\begin{array}{l}1, \\
\text { C }\end{array}$ & A \\
\hline 17903 & Panglao 2004 & S12 & $9^{\circ} 29.4^{\prime} \mathrm{N}, 123^{\circ} 56.0^{\prime} \mathrm{E}, 6-8 \mathrm{~m}$ & Eucyclotoma Boettger, 1895 & $\mathrm{x}$ & $\mathrm{x}$ & $\mathrm{x}$ & $\mathrm{x}$ & 10 & $\mathrm{~B}$ \\
\hline 17904 & Panglao 2004 & T9 & $9^{\circ} 33.5 \mathrm{~N}, 123^{\circ} 49.5^{\prime} \mathrm{E}, 97-120 \mathrm{~m}$ & cf. Nannodiella Dall, 1919 & $\mathrm{x}$ & $\mathrm{x}$ & $\mathrm{x}$ & $\mathrm{x}$ & 12 & $\mathrm{~B}$ \\
\hline 17905 & Panglao 2005 & CP2348 & $9^{\circ} 29.6^{\prime} \mathrm{N}, 123^{\circ} 52.5^{\prime} \mathrm{E}, 196-216 \mathrm{~m}$ & Otitoma Jousseaume, 1898 & $\mathrm{x}$ & $\mathrm{x}$ & $\mathrm{x}$ & $\mathrm{x}$ & $\begin{array}{l}2, \\
\text { C }\end{array}$ & A \\
\hline 17906 & Panglao 2005 & CP2349 & $9^{\circ} 31.6^{\prime} \mathrm{N}, 123^{\circ} 55.7^{\prime} \mathrm{E}, 219-240 \mathrm{~m}$ & Ptychobela Thiele, 1925 & $\mathrm{x}$ & $\mathrm{x}$ & $\mathrm{x}$ & $\mathrm{x}$ & $\begin{array}{l}2, \\
\text { C }\end{array}$ & $\mathrm{A}$ \\
\hline 17907 & Panglao 2005 & CP2349 & $9^{\circ} 31.6^{\prime} \mathrm{N}, 123^{\circ} 55.7^{\prime} \mathrm{E}, 219-240 \mathrm{~m}$ & Gemmula Weinkauff, 1875 & $\mathrm{x}$ & $\mathrm{x}$ & $\mathrm{x}$ & $\mathrm{x}$ & 5 & A \\
\hline 17908 & Panglao 2005 & CP2332 & $9^{\circ} 38.8^{\prime} \mathrm{N}, 123^{\circ} 45.9^{\prime} \mathrm{E}, 396-418 \mathrm{~m}$ & Iwaoa Kuroda, 1953 & $\mathrm{x}$ & $\mathrm{x}$ & $\mathrm{x}$ & $\mathrm{x}$ & 7 & A \\
\hline 17909 & Panglao 2005 & CP2343 & $9^{\circ} 27.4^{\prime} \mathrm{N}, 123^{\circ} 49.4^{\prime} \mathrm{E}, 273-356 \mathrm{~m}$ & Cinguloterebra cf. fujitai Kuroda and Habe, 1952 & $\mathrm{x}$ & $\mathrm{x}$ & $\mathrm{x}$ & $\mathrm{x}$ & 6 & $\mathrm{~A}$ \\
\hline 17910 & Panglao 2005 & CP2349 & $9^{\circ} 31.6^{\prime} \mathrm{N}, 123^{\circ} 55.7^{\prime} \mathrm{E}, 219-240 \mathrm{~m}$ & Tomopleura Casey, 1924 & $\mathrm{x}$ & $\mathrm{x}$ & $\mathrm{x}$ & $\mathrm{x}$ & 14 & $\mathrm{~B}$ \\
\hline 17911 & Panglao 2005 & CP2333 & $9^{\circ} 38.2^{\prime} \mathrm{N}, 123^{\circ} 43.5^{\prime} \mathrm{E}, 584-596 \mathrm{~m}$ & cf. Heteroturris Powell, 1967 & $\mathrm{x}$ & $\mathrm{x}$ & $\mathrm{x}$ & $\mathrm{x}$ & 18 & $\mathrm{~B}$ \\
\hline 17912 & Panglao 2005 & CP2377 & $8^{\circ} 40.6^{\prime} \mathrm{N}, 123^{\circ} 20.3^{\prime} \mathrm{E}, 85-88 \mathrm{~m}$ & Conus praecellens Adams, 1854 & $\mathrm{x}$ & $\mathrm{x}$ & $\mathrm{x}$ & $\mathrm{x}$ & 19 & $\mathrm{~B}$ \\
\hline $17913^{*}$ & Panglao 2005 & CP2377 & $8^{\circ} 40.6^{\prime} \mathrm{N}, 123^{\circ} 20.3^{\prime} \mathrm{E}, 85-88 \mathrm{~m}$ & Conus sulcatus Hwass in Bruguière, 1792 & $\mathrm{x}$ & $\mathrm{x}$ & $\mathrm{x}$ & $\mathrm{x}$ & 19 & $\mathrm{~B}$ \\
\hline 17914 & Panglao 2005 & CP2380 & $8^{\circ} 41.3^{\prime} \mathrm{N}, 123^{\circ} 17.8^{\prime} \mathrm{E}, 150-163 \mathrm{~m}$ & Conus sulcatus Hwass in Bruguière, 1792 & $\mathrm{x}$ & $\mathrm{x}$ & $\mathrm{x}$ & $\mathrm{x}$ & 21 & $\mathrm{~B}$ \\
\hline 17915 & Panglao 2005 & CP2381 & $8^{\circ} 43.3^{\prime} \mathrm{N}, 123^{\circ} 19.0^{\prime} \mathrm{E}, 259-280 \mathrm{~m}$ & Toxicochlespira Sysoev and Kantor, 1990 & $\mathrm{x}$ & $\mathrm{x}$ & $\mathrm{x}$ & $\mathrm{x}$ & 17 & $\mathrm{~B}$ \\
\hline $17916^{*}$ & Panglao 2005 & CP2385 & $8^{\circ} 51.0^{\prime} \mathrm{N}, 123^{\circ} 10.0^{\prime} \mathrm{E}, 982-989 \mathrm{~m}$ & Comitas Finlay, 1926 & $\mathrm{x}$ & $\mathrm{x}$ & $\mathrm{x}$ & $\mathrm{x}$ & $\begin{array}{l}4, \\
\mathrm{C}\end{array}$ & A \\
\hline 17917 & Panglao 2005 & СР2393 & $9^{\circ} 30.1^{\prime} \mathrm{N}, 123^{\circ} 41.6^{\prime} \mathrm{E}, 356-396 \mathrm{~m}$ & Terebra polygirata Deshayes, 1859 & $\mathrm{x}$ & $\mathrm{x}$ & $\mathrm{x}$ & $\mathrm{x}$ & 6 & A \\
\hline 17918 & Panglao 2005 & CP2388 & $9^{\circ} 26.9^{\prime} \mathrm{N}, 123^{\circ} 34.5^{\prime} \mathrm{E}, 762-786 \mathrm{~m}$ & Comitas Finlay, 1926 & $\mathrm{x}$ & $\mathrm{x}$ & $\mathrm{x}$ & $\mathrm{x}$ & $\begin{array}{l}4, \\
\mathrm{C}\end{array}$ & $\mathrm{A}$ \\
\hline 17919 & Panglao 2005 & CP2340 & $9^{\circ} 29.4^{\prime} \mathrm{N}, 123^{\circ} 44.4^{\prime} \mathrm{E}, 271-318 \mathrm{~m}$ & Cochlespira Conrad, 1865 & $\mathrm{x}$ & $\mathrm{x}$ & $\mathrm{x}$ & & 8 & $\mathrm{~A}$ \\
\hline 17920 & Panglao 2005 & CP2340 & $9^{\circ} 29.4^{\prime} \mathrm{N}, 123^{\circ} 44.4^{\prime} \mathrm{E}, 271-318 \mathrm{~m}$ & Cochlespira Conrad, 1865 & $\mathrm{x}$ & $\mathrm{x}$ & $\mathrm{x}$ & & 8 & A \\
\hline $17921^{*}$ & Panglao 2005 & CP2340 & $9^{\circ} 29.4^{\prime} \mathrm{N}, 123^{\circ} 44.4^{\prime} \mathrm{E}, 271-318 \mathrm{~m}$ & Conus orbignyi Kilburn, 1975 & $\mathrm{x}$ & $\mathrm{x}$ & $\mathrm{x}$ & $\mathrm{x}$ & 21 & $\mathrm{~B}$ \\
\hline
\end{tabular}




\begin{tabular}{|c|c|c|c|c|c|c|c|c|c|c|}
\hline 17922 & Panglao 2005 & DW2400 & $9^{\circ} 32.5^{\prime} \mathrm{N}, 123^{\circ} 41.8^{\prime} \mathrm{E}, 111-115 \mathrm{~m}$ & Conus wakayamaensis Kuroda, 1956 & $\mathrm{x}$ & $\mathrm{x}$ & $\mathrm{x}$ & $\mathrm{x}$ & 21 & $\mathrm{~B}$ \\
\hline 17923 & Panglao 2005 & CP2395 & $9^{\circ} 36.2^{\prime} \mathrm{N}, 123^{\circ} 43.8^{\prime} \mathrm{E}, 382-434 \mathrm{~m}$ & Cinguloterebra cf. fenestrata Hinds, 1844 & $\mathrm{x}$ & $\mathrm{x}$ & $\mathrm{x}$ & $\mathrm{x}$ & 6 & A \\
\hline 17924 & Salomon 2 & CP2184 & $8^{\circ} 16,9^{\prime}$ S, $159^{\circ} 59,7^{\prime}$ E, $464-523 \mathrm{~m}$ & Thatcheria Angas, 1877 & $\mathrm{x}$ & $\mathrm{x}$ & $\mathrm{x}$ & $\mathrm{x}$ & 10 & $\mathrm{~B}$ \\
\hline 17925 & Salomon 2 & CP2227 & $6^{\circ} 37,2^{\prime} \mathrm{S}, 156^{\circ} 12,7^{\prime} \mathrm{E}, 508-522 \mathrm{~m}$ & Toxicochlespira Sysoev and Kantor, 1990 & $\mathrm{x}$ & $\mathrm{x}$ & $\mathrm{x}$ & $\mathrm{x}$ & 17 & $\mathrm{~B}$ \\
\hline $17926^{*}$ & Salomon 2 & CP2269 & $7^{\circ} 45,1^{\prime} \mathrm{S}, 156^{\circ} 56,3^{\prime} \mathrm{E}, 768-890 \mathrm{~m}$ & Borsonia Bellardi, 1839 & $\mathrm{x}$ & $\mathrm{x}$ & $\mathrm{x}$ & $\mathrm{x}$ & 15 & $\mathrm{~B}$ \\
\hline 17927 & Salomon 2 & CP2260 & $8^{\circ} 03,5^{\prime} \mathrm{S}, 156^{\circ} 54,5^{\prime} \mathrm{E}, 399-427 \mathrm{~m}$ & Daphnella Hinds, 1844 & $\mathrm{x}$ & $\mathrm{x}$ & $\mathrm{x}$ & $\mathrm{x}$ & 10 & $\mathrm{~B}$ \\
\hline 17929 & Salomon 2 & CP2186 & $8^{\circ} 17,0^{\prime} \mathrm{S}, 160^{\circ} 00,0^{\prime} \mathrm{E}, 487-541 \mathrm{~m}$ & Bathytoma Harris and Burrows, 1891 & $\mathrm{x}$ & $\mathrm{x}$ & $\mathrm{x}$ & $\mathrm{x}$ & 20 & $\mathrm{~B}$ \\
\hline 17930 & Salomon 2 & CP2269 & $7^{\circ} 45,1^{\prime} \mathrm{S}, 156^{\circ} 56,3^{\prime}$ E, 768-890m & Benthomangelia Thiele, 1925 & $\mathrm{x}$ & $\mathrm{x}$ & $\mathrm{x}$ & $\mathrm{x}$ & 17 & $\mathrm{~B}$ \\
\hline 17931 & Salomon 2 & CP2269 & $7^{\circ} 45,1^{\prime} \mathrm{S}, 156^{\circ} 56,3^{\prime} \mathrm{E}, 768-890 \mathrm{~m}$ & cf. Typhlomangelia Sars, 1878 & $\mathrm{x}$ & $\mathrm{x}$ & $\mathrm{x}$ & $\mathrm{x}$ & 18 & $\mathrm{~B}$ \\
\hline 17932 & Salomon 2 & CP2197 & $\begin{array}{c}8^{\circ} 24,4^{\prime} \mathrm{S}, 159^{\circ} 22,5^{\prime} \mathrm{E}, 897- \\
1057 \mathrm{~m}\end{array}$ & Borsonia Bellardi, 1839 & $\mathrm{x}$ & $\mathrm{x}$ & $\mathrm{x}$ & $\mathrm{x}$ & 15 & $\mathrm{~B}$ \\
\hline 17933 & Salomon 2 & CP2228 & $6^{\circ} 34,7^{\prime} \mathrm{S}, 156^{\circ} 10,5^{\prime} \mathrm{E}, 609-625 \mathrm{~m}$ & Comitas Finlay, 1926 & $\mathrm{x}$ & $\mathrm{x}$ & $\mathrm{x}$ & $\mathrm{x}$ & $\begin{array}{l}3, \\
\mathrm{C}\end{array}$ & A \\
\hline 17934 & Salomon 2 & CP2176 & $9^{\circ} 09,4^{\prime} \mathrm{S}, 158^{\circ} 59,2^{\prime} \mathrm{E}, 600-875 \mathrm{~m}$ & Borsonia Bellardi, 1839 & $\mathrm{x}$ & $\mathrm{x}$ & $\mathrm{x}$ & $\mathrm{x}$ & 16 & $\mathrm{~B}$ \\
\hline 17935 & Salomon 2 & CP2187 & $8^{\circ} 17,5^{\prime} \mathrm{S}, 159^{\circ} 59,8^{\prime} \mathrm{E}, 482-604 \mathrm{~m}$ & Inquisitor Hedley, 1918 & $\mathrm{x}$ & $\mathrm{x}$ & $\mathrm{x}$ & $\mathrm{x}$ & $\begin{array}{l}2, \\
\text { C }\end{array}$ & A \\
\hline 17936 & Santo 2006 & LD28 & $15^{\circ} 35,4^{\prime} \mathrm{S}, 166^{\circ} 58,7^{\prime} \mathrm{E}, 3-8 \mathrm{~m}$ & Conus generalis Linne, 1758 & $\mathrm{x}$ & $\mathrm{x}$ & $\mathrm{x}$ & $\mathrm{x}$ & 19 & $\mathrm{~B}$ \\
\hline 17937 & Santo 2006 & NR52 & $15^{\circ} 35,6 \mathrm{~S}, 167^{\circ} 01,9 \mathrm{E}, 15 \mathrm{~m}$ & Conus gauguini Richard and Salvat, 1973 & $\mathrm{x}$ & $\mathrm{x}$ & $\mathrm{x}$ & $\mathrm{x}$ & 19 & $\mathrm{~B}$ \\
\hline $17938^{*}$ & Santo 2006 & LD28 & $15^{\circ} 35,4^{\prime} \mathrm{S}, 166^{\circ} 58,7^{\prime} \mathrm{E}, 3-8 \mathrm{~m}$ & Terebra textilis Hinds, 1844 & $\mathrm{x}$ & $\mathrm{x}$ & $\mathrm{x}$ & $\mathrm{x}$ & 6 & A \\
\hline 17939 & Santo 2006 & AT87 & $15^{\circ} 32,1^{\prime} \mathrm{S}, 167^{\circ} 16,1^{\prime} \mathrm{E}, 235-271 \mathrm{~m}$ & Conus consors Sowerby, 1833 & $\mathrm{x}$ & $\mathrm{x}$ & $\mathrm{x}$ & $\mathrm{x}$ & 19 & $\mathrm{~B}$ \\
\hline 17854 & Norfolk 2 & DW2034 & $23^{\circ} 41^{\prime} \mathrm{S}, 167^{\circ} 41^{\prime} \mathrm{E}, 485-505 \mathrm{~m}$ & Nassaria, Buccinidae & $\mathrm{x}$ & $\mathrm{x}$ & $\mathrm{x}$ & $\mathrm{x}$ & & \\
\hline 17856 & Norfolk 2 & DW2081 & $25^{\circ} 54^{\prime} \mathrm{S}, 168^{\circ} 22^{\prime} \mathrm{E}, 500-505 \mathrm{~m}$ & Cancellopollia, Buccinidae & $\mathrm{x}$ & $\mathrm{x}$ & $\mathrm{x}$ & $\mathrm{x}$ & & \\
\hline GenBank & & & & Littorina, Littorinidae & $\mathrm{x}$ & $\mathrm{x}$ & $\mathrm{x}$ & $\mathrm{x}$ & & \\
\hline
\end{tabular}

Identification number (ID) corresponding to MNHN catalogue number, cruise and station of collection, with the coordinates and the depth, are given for each specimen. Specimens are identified at genus level, except Conus and Terebridae which are identified at species level. A cross indicates that the specimen was successfully sequenced for the gene. Allocation to clades A, B, C and 1-22, as defined by the molecular analysis, is given for each taxon. ${ }^{\mathrm{a}}$ This specimen has been chosen to illustrate the clade to which it belongs in Fig. 1. 
Table 3: Models of evolution and parameters estimated using AIC implemented in Modeltest for each gene separately and each combined dataset.

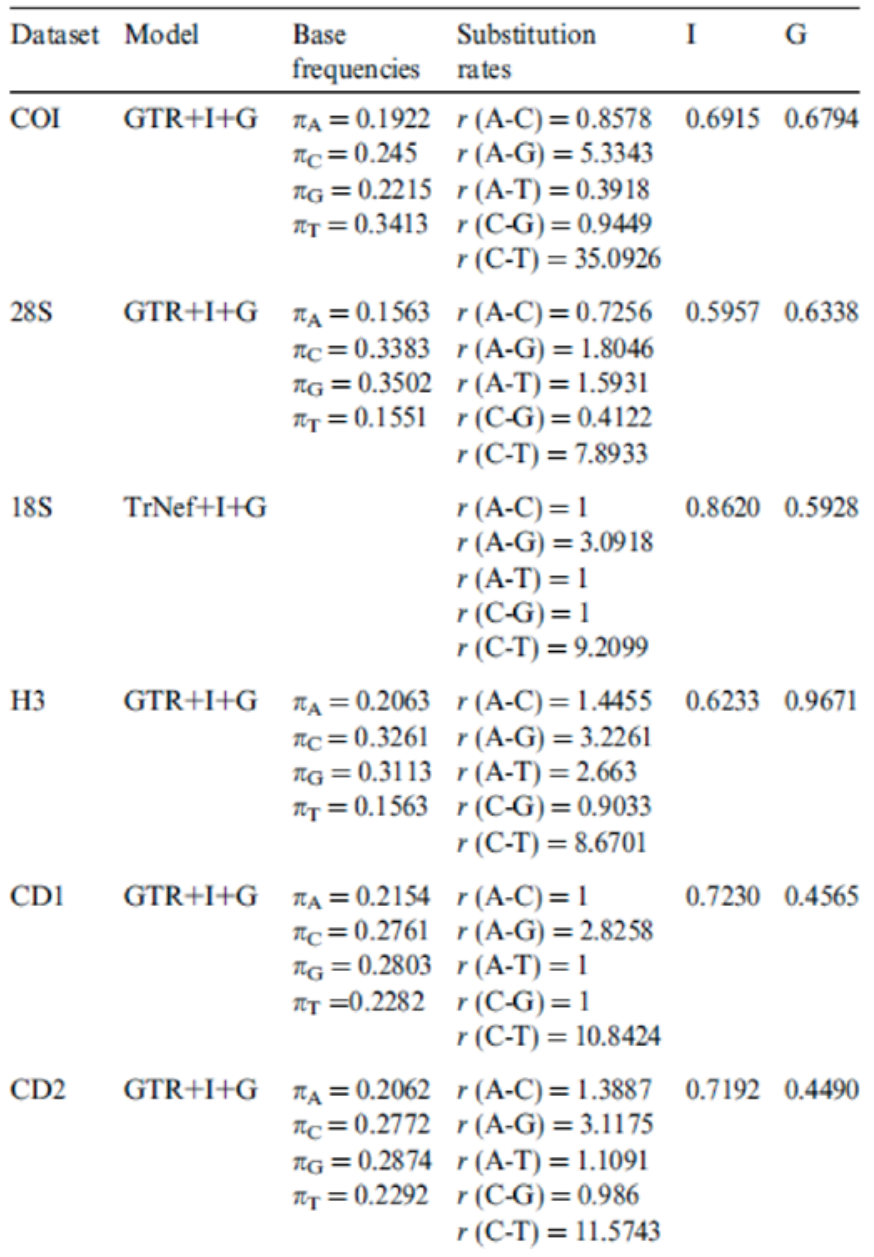

Proportion of invariable sites; G, gamma rate distribution; CD, combined dataset. 
Table 4: Node supports of ML, MP and BA analyses for the four genes separately and for the two combined datasets.

665

\begin{tabular}{|c|c|c|c|c|c|c|c|c|c|c|c|c|c|c|c|c|c|c|}
\hline & \multicolumn{3}{|l|}{$\mathrm{COI}$} & \multicolumn{3}{|l|}{$28 \mathrm{~S}$} & \multicolumn{3}{|l|}{$18 \mathrm{~S}$} & \multicolumn{3}{|l|}{$\mathrm{H} 3$} & \multicolumn{3}{|l|}{ CD1 } & \multicolumn{3}{|l|}{$\mathrm{CD} 2$} \\
\hline & ML & MP & $\mathrm{BA}$ & ML & MP & $\mathrm{BA}$ & ML & MP & $\mathrm{BA}$ & ML & MP & BA & ML & MP & BA & ML & MP & $\mathrm{BA}$ \\
\hline Conoidea & & & & & & & 35 & & 0.94 & & & & 85 & 71 & 0.98 & 79 & 65 & 1 \\
\hline Clade A & 1 & & & & & & 13 & & & 6 & & 0.6 & 85 & 70 & 0.88 & 68 & 58 & 0.73 \\
\hline Clade B & & & & & & 1 & & & & & & & 53 & 33 & 0.52 & 52 & 28 & 1 \\
\hline Clade C & & & & 34 & 30 & 0.98 & & & & 41 & 40 & & 89 & 81 & 1 & 91 & 76 & 1 \\
\hline Clade 1 & & & & 99 & 92 & 1 & 99 & & 1 & 66 & 43 & 0.54 & 100 & 100 & 1 & 100 & 100 & 1 \\
\hline Clade 2 & 11 & 9 & & & & & 7 & 28 & 0.96 & & 32 & & 84 & 84 & 1 & 84 & 85 & 1 \\
\hline Clade 3 & 57 & 46 & & 95 & 95 & 0.83 & & 63 & 0.96 & 100 & 98 & 0.95 & 100 & 100 & 1 & 100 & 100 & 1 \\
\hline Clade 4 & 93 & 92 & 0.96 & 100 & 100 & 1 & & 1 & & 100 & 99 & 0.98 & 100 & 100 & 1 & 100 & 100 & 1 \\
\hline Clade 5 & 27 & 17 & 1 & 54 & 34 & 0.98 & & & & 32 & 72 & 0.99 & 100 & 93 & 1 & 100 & 97 & 1 \\
\hline Clade 6 & 53 & 26 & 1 & 86 & 93 & 1 & 34 & 44 & 0.96 & 58 & 70 & 0.63 & 100 & 98 & 1 & 100 & 100 & 1 \\
\hline Clade 7 & & 36 & 0.57 & 90 & 87 & 0.94 & & & & 41 & 21 & 0.53 & 100 & 97 & 1 & 100 & 99 & 1 \\
\hline Clade 8 & 98 & 100 & 1 & 99 & 99 & 1 & 62 & 55 & 1 & & & & & & & 100 & 100 & 1 \\
\hline Clade 9 & 100 & 100 & 1 & 100 & 100 & 1 & & 0 & & 100 & 100 & 1 & 100 & 100 & 1 & 100 & 100 & 1 \\
\hline Clade 10 & & & & 90 & 80 & 1 & & & & & 16 & & 100 & 100 & 1 & 98 & 95 & 1 \\
\hline Clade 11 & & & & 99 & 99 & 1 & & & & 42 & 23 & 0.77 & 100 & 99 & 1 & 100 & 100 & 1 \\
\hline Clade 12 & & & & 97 & 87 & 1 & 59 & 52 & 1 & 45 & 26 & 0.95 & 100 & 95 & 1 & 100 & 92 & 1 \\
\hline Clade 13 & 23 & 27 & 0.55 & 97 & 98 & 1 & 92 & 88 & 1 & 46 & 46 & & 100 & 100 & 1 & 100 & 100 & 1 \\
\hline Clade 14 & 75 & 62 & 1 & 72 & 66 & 0.92 & & & & 70 & 81 & 0.65 & 99 & 100 & 1 & 100 & 100 & 1 \\
\hline Clade 15 & 100 & 98 & 1 & 100 & 98 & 1 & 88 & 62 & 0.98 & 100 & 100 & 1 & 100 & 100 & 1 & 100 & 100 & 1 \\
\hline Clade 16 & 38 & 56 & & 31 & & & & & & 56 & 48 & 0.99 & 97 & 93 & 1 & 98 & 95 & 1 \\
\hline Clade 17 & & 15 & & 24 & 20 & & 56 & 57 & 0.98 & 96 & 94 & 1 & 99 & 100 & 1 & 99 & 100 & 1 \\
\hline Clade 18 & 91 & 90 & 1 & & 16 & & & & & 64 & 51 & 0.87 & 98 & 93 & 1 & 96 & 86 & 1 \\
\hline Clade 19 & & & & 100 & 100 & 1 & 100 & 98 & 1 & 99 & 100 & 1 & 100 & 100 & 1 & 100 & 100 & 1 \\
\hline Clade 20 & & & & 100 & 100 & 1 & & & & 87 & 74 & 0.94 & 100 & 100 & 1 & 100 & 100 & 1 \\
\hline Clade 21 & 99 & 97 & 1 & 89 & 84 & 1 & & & & 95 & 97 & 1 & 100 & 100 & 1 & 100 & 100 & 1 \\
\hline Clade 22 & 56 & 52 & 0.88 & & & & & & & & & & & & & & & \\
\hline
\end{tabular}

Bootstraps values and Posterior Probabilities are given for 26 nodes (all Conoidea, clades A, B, C and clades 1-22). CD, Combined dataset. Gray cells correspond to unavailable data (sequences for specimens attributed to clade 8 were not obtained for $\mathrm{H} 3$ gene, and sequences for those attributed to clade 22 were successfully sequenced only for COI gene). 
Table 5: Genera included in the clades A, B, C and 1-22, and association to a taxonomic name proposed in previous classifications (see Table 1).

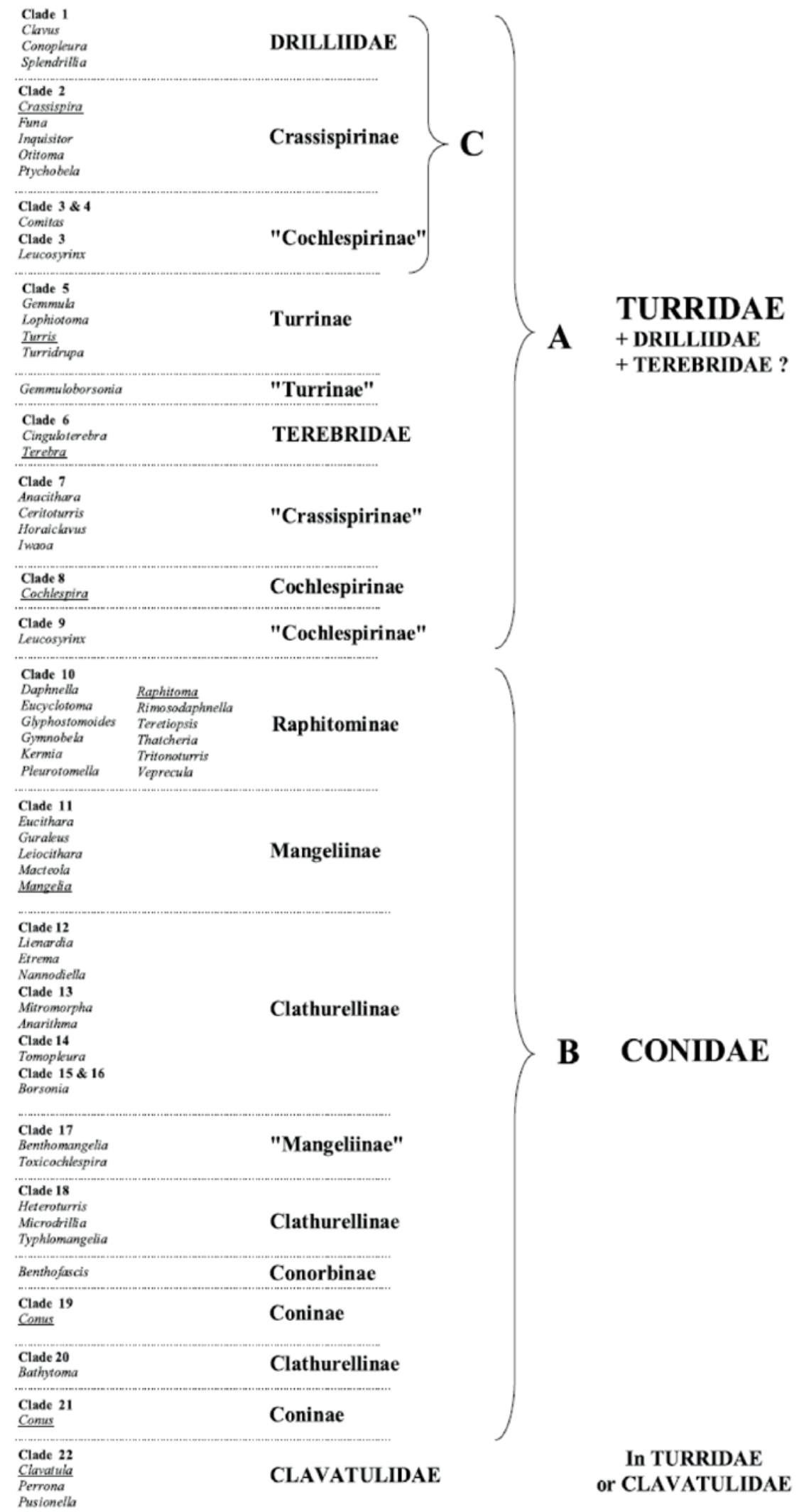

Subfamilies are in bold, families in bold and capital. Type genera present in our dataset are underlined. 
Fig. 1. Consensus tree of MP, ML and BA results obtained with CD2. Nodes presented here were found with at least two of the three methods used. Top downwards, MP bootrstraps, ML boostraps and Posterior Probabilities are specified for each node. Supports for intranodes of clades 1-21 are not presented. Taxonomic names are attributed for each of the clades $1-21$, as explained in the text. One example of shell, corresponding to the type-genus when possible, is given for each clade. Illustrated specimens are quoted in the Table 2.

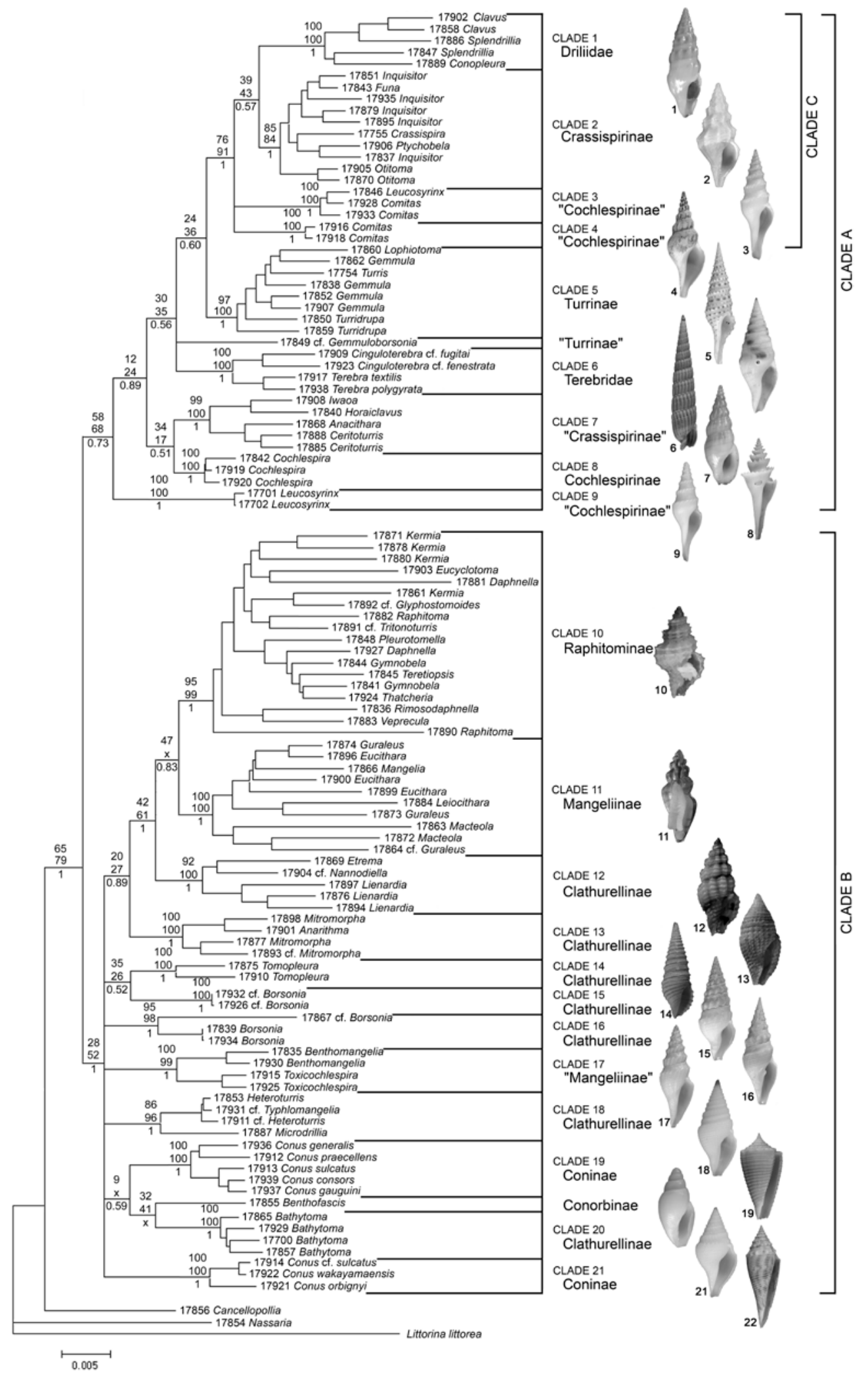

